Working Paper 94-12 / Document de travail 94-12

Searching for the Liquidity Effect in Canada

by

Ben Fung and Rohit Gupta

Bank of Canada Banque du Canada 

December 1994

\title{
Searching for the Liquidity Effect in Canada
}

\author{
by \\ Ben S. C. Fung and Rohit Gupta \\ Department of Monetary and Financial Analysis \\ Bank of Canada \\ Ottawa, Ontario \\ Canada \\ K1A 0G9
}

Tel.: (613) 782-7582

Fax: (613) 782-7508

The views expressed here are those of the authors.

No responsibility for them should be attributed to the Bank of Canada. 


\section{Acknowledgments}

An earlier version of this paper was presented at the Canadian Economics Association meetings in Calgary, 10-13 June 1994. We would like to thank Kevin Clinton, Walter Engert and Jack Selody for very helpful discussions and suggestions. The paper has also benefited from comments by Pierre Duguay, Chuck Freedman, Donna Howard, Dave Longworth and seminar participants at the Bank of Canada. We also thank the Securities Department of the Bank and especially Glen Snow for compiling the data on excess cash reserves. Jamie Armour provided additional research assistance for the current version of this paper. Of course, all errors are our own.

ISSN 1192-5434

ISBN 0-662-22804-9

Printed in Canada on recycled paper 


\section{Contents}

Abstract/ Résumé ........................................................................................... V

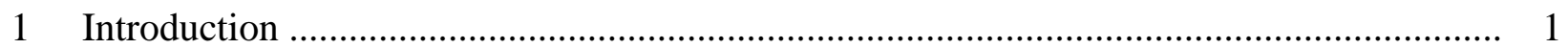

2 A review of the empirical work on liquidity effects ............................................. 4

3 Methodology: structural vector autoregression and identification ............................ 7

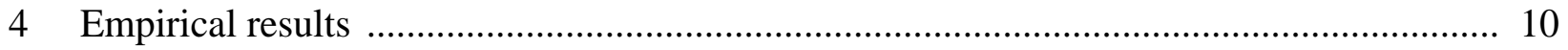

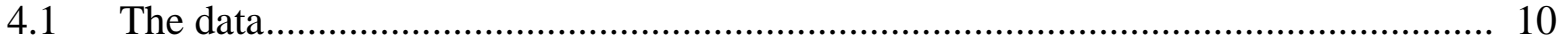

4.1.1 Liquidity measures......................................................................... 10

4.1.2 Rates and macro-variables .................................................................. 11

4.2 The dynamic responses ......................................................................... 12

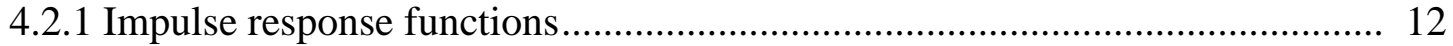

4.2.2 Variance decompositions ................................................................. 15

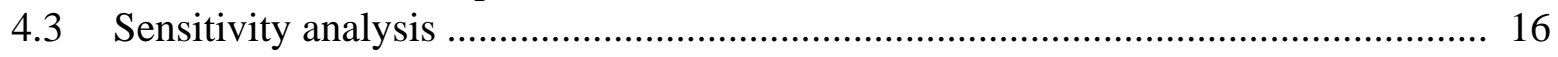

4.3.1 Sample period sensitivity tests............................................................. 16

4.3.2 Sensitivity with respect to different measures of interest rates...................... 17

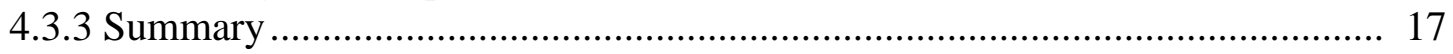

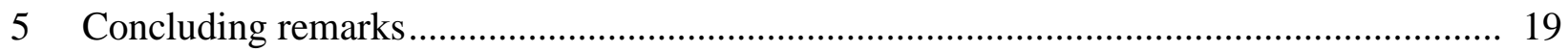

Appendix 1: Description of the data ........................................................................ 21

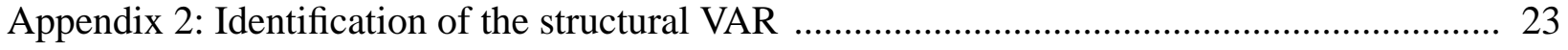

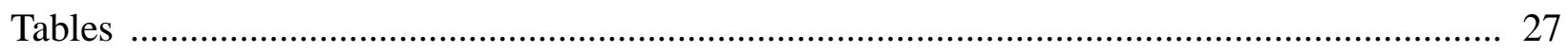

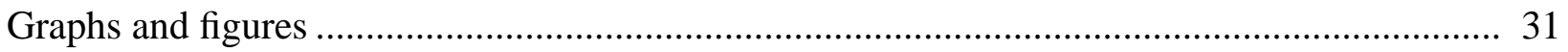

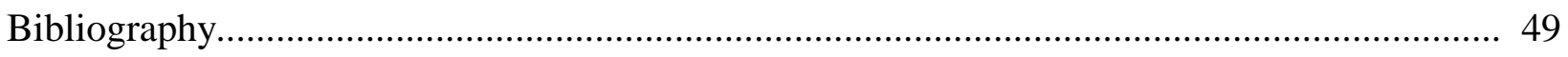





\begin{abstract}
This paper examines the empirical evidence of the liquidity effect in Canada. In the presence of the liquidity effect, the initial impact of an unanticipated expansionary monetary policy is to lower nominal and real interest rates for a short period of time. Eventually, however, the anticipated inflation effect will come into force and dominate the liquidity effect as people adjust their inflation expectations to the new money growth rate. As a result, interest rates will then increase. In this paper, we use vector autoregression (VAR) methods to study how interest rates, output and exchange rates respond to shocks to monetary policy. We use the excess cash reserves of the chartered banks and the surprise component of excess cash reserves as measures of monetary policy shocks. Shocks to monetary policy are measured by the orthogonalized innovations to these liquidity variables. We find that expansionary shocks to monetary policy are followed by declines in the interest rate, increases in output, and depreciations of the Canadian dollar. The results are robust to different orderings of the variables used in the VAR estimation. The response of the interest rate to monetary policy shocks is robust to different measures of liquidity, but the responses of other variables vary slightly.
\end{abstract}

\title{
Résumé
}

Les auteurs examinent empiriquement la pertinence des effets de liquidité au Canada. Sous l'hypothèse d'effet de liquidité, l'incidence initiale d'un choc expansionniste non anticipé de la politique monétaire consiste en une diminution momentanée des taux d'intérêt nominaux et réels. Cependant, comme les anticipations d'inflation s'ajustent au nouveau taux d'expansion monétaire, leur effet finit par se manifester et dominer l'effet de liquidité. Les taux d'intérêt se mettent alors à augmenter. Dans leur étude, les auteurs font appel à la méthode d'estimation des vecteurs autorégressifs pour étudier comment les taux d'intérêt, la production et les taux de change réagissent aux chocs de politique monétaire. Ils se servent des réserves excédentaires des banques à charte et de leur composante non anticipée comme mesures des chocs de la politique monétaire. Plus précisément, ceux-ci sont mesurés par les innovations orthogonalisées de ces variables de liquidité. Les auteurs ont observé que les chocs expansionnistes de politique monétaire sont suivis par des baisses de taux d'intérêt, des hausses de la production et des dépréciations du dollar canadien. Les résultats obtenus résistent bien aux changements d'agencement des variables utilisées dans l'estimation des vecteurs autorégressifs. La réaction des taux d'intérêt aux chocs de politique monétaire est peu sensible aux diverses mesures de liquidité utilisées, mais la réaction des autres variables a tendance à varier légèrement. 



\section{Introduction}

The purpose of this paper is to examine the empirical evidence of the liquidity effect in Canada. In particular, we investigate how strong and persistent the liquidity effect is. In the presence of such an effect, the initial impact of an unanticipated expansionary monetary policy is to lower nominal and real interest rates for a short period of time. Eventually, however, the anticipated inflation effect will come into force and dominate the liquidity effect as people adjust their inflation expectations to the new money growth rate. As a result, interest rates will then increase. The strength of the liquidity effect can be measured by the size of the negative response of interest rates to expansionary policy, and its persistence can be measured by the length of time before interest rates start to rise.

According to the prevailing view, the Bank of Canada influences very short-term interest rates, such as the call loan rate, by varying the supply of settlement balances. The level of the call loan rate is targeted with a view towards achieving a particular level of monetary conditions, expressed as a linear combination of the 90-day interest rate and the trade-weighted exchange rate. The movements in interest rates and the exchange rate then affect consumer spending, investment and net exports, resulting in a change in aggregate demand and output (an openeconomy IS curve relationship). The level of aggregate demand relative to aggregate supply puts pressure on the inflation rate through a Phillips curve relationship. ${ }^{1}$ Our paper will focus on the empirical evidence of the effect of policy-induced shocks to the supply of settlement balances on the call loan rate.

Recently, there has been a surge of interest and significant progress in the study of the liquidity effect. Empirical studies by Christiano and Eichenbaum (1992a) and Strongin (1992) find strong evidence supporting the presence of liquidity effects in the United States. General equilibrium models by Lucas (1990), Furest (1992), and Christiano and Eichenbaum (1992b), developed along the lines of Grossman and Weiss (1983) and Rotemberg (1984), have been successful in generating a strong and persistent liquidity effect. These models consist of four different agents: the household, the firm, the monetary authority and the financial intermediary, and they rely on the heterogeneous impacts of monetary policy to generate the liquidity effect. One attractive feature of these models is that money and financial intermediaries play very important roles: money is required by firms to finance production and by consumers to purchase consumption goods, and any monetary injections are transmitted to the economy through

1. This is a highly simplified description of the current Bank of Canada view. For a detailed review, see Crow (1988) and Duguay (1994). 
financial intermediaries. The key assumption is that households cannot continuously revise their consumption and savings decisions. ${ }^{2}$ Thus, after a money shock, for example a monetary expansion, households cannot immediately adjust the quantity of cash spent on consumption to the changed financial market circumstances. The intermediaries, which have become more liquid because of the newly injected cash, have to lower the interest rate to encourage firms to borrow more. As a result, investment and business activities are stimulated and production is increased. As incomes rise, households will also adjust their consumption and savings decisions, and the price level will eventually adjust to the new money growth rate.

Liquidity-effect models are interesting because they provide a view of the transmission mechanism in which money and financial intermediaries play important roles. As the Bank of Canada injects settlement balances into the payments system, the direct-clearing financial institutions - in particular, the major chartered banks - become more liquid because of the cash injection. Since deposits at the Bank of Canada pay no interest, the banks attempt to dispose of the extra cash by lending it to investment dealers in the special call loan market, thus increasing their holdings of earning liquid assets and putting downward pressure on the call loan rate. Moreover, the banks may desire to increase their holdings of less liquid assets by making loans more available and at a lower rate, especially when they perceive the cash injections as an easy monetary policy. The additional liquidity stimulates borrowing, thus increasing investment and economic activity. As employment and wages increase, households revise their consumptionsavings decisions. Eventually, the price level will adjust to the increase in liquidity and the system will move back to an equilibrium.

In this paper, we use vector autoregression (VAR) methods to study how interest rates, output and exchange rates respond to shocks to monetary policy. Several studies in the liquidityeffect literature argue that inference about the effects of monetary policy on interest rates depends critically on the identification assumptions adopted to measure the exogenous component of changes in monetary policy and on the measure of liquidity used. The most widely used measures of monetary policy shocks, such as innovations to conventional monetary aggregates, are inconsistent with the actual operating procedures of the Bank of Canada or the Federal Reserve. Moreover, Christiano and Eichenbaum (1992a) and Strongin (1992) report that in the United States the use of these types of measures, for example, M1, leads to misleading inferences.

2. Christiano, Eichenbaum and Evans (1994) study the flows-of-funds data in the United States and find that net funds raised by the household sector remain unchanged for several quarters after a monetary shock. This finding is consistent with the assumption that households do not adjust their consumption-savings decisions immediately after a monetary shock. 
Therefore, in this paper, we use the excess cash reserves of the chartered banks and the surprise component of excess cash as measures of monetary policy shocks. ${ }^{3}$ Shocks to monetary policy are measured by the orthogonalized innovations to these liquidity variables.

The major findings of the paper can be summarized as follows. We find that when excess cash is used as a measure of liquidity, expansionary shocks to monetary policy are followed by declines in the interest rate, increases in output, and depreciations of the Canadian dollar. The results are robust to different orderings of the variables used in the VAR estimation. The response of the interest rate to monetary policy shocks is robust to different measures of liquidity, but the responses of other variables vary slightly. The evidence on the liquidity effect is strongest when excess cash is employed as the measure of liquidity. This result is consistent with the view that the Bank of Canada implements its policy by controlling the supply of excess cash to the financial system. Our findings are in line with similar studies in the United States. However, liquidity effects in Canada are relatively short-lived compared to the empirical results reported in Christiano and Eichenbaum (1992a) and Strongin (1992), lasting for about three to six months. When the non-borrowed reserve mix (NBRX) is used as the liquidity measure over the period 1959:1 to 1992:2, Strongin finds that a one-standard deviation shock in NBRX causes the federal funds rate to decline for almost seven months. ${ }^{4}$ Christiano and Eichenbaum find that the liquidity effect lasts for almost four years when non-borrowed reserves (NBR) are used in their analysis. ${ }^{5}$ The relatively short-lived liquidity effect in Canada may be due to the fact that, over the sample period 1977 to 1991, people had built up highly sensitive inflationary expectations so that the liquidity effect was quickly dominated by the anticipated inflation effect a few months after the money supply shock. Moreover, the sample period that we use in this study is short compared to the studies by Strongin and Christiano and Eichenbaum.

The remainder of the paper is organized as follows. Section 2 briefly reviews the empirical work on liquidity effects. Section 3 describes the methodology and discusses the identification of the structural VAR. Section 4 presents the empirical results. The final section offers some concluding remarks.

3. Detailed descriptions of these cash reserve measures can be found in Section 4 and Appendix 1.

4. NBRX is the ratio of non-borrowed reserves to the lag of total reserves.

5. NBR is total reserves less total borrowings from the Federal Reserve by depository institutions. 


\section{A review of the empirical work on liquidity effects}

There has been much debate about the empirical evidence of the liquidity effect. However, recent empirical studies, most notably Christiano and Eichenbaum (1992a) and Strongin (1992), argue that there is strong evidence of the presence of liquidity effects in the United States. These studies suggest that NBR is the best measure of money in the United States and that the liquidity effect is a significant and persistent feature of the U.S. economy. In this section, we briefly review some of the empirical studies on liquidity effects in the United States. These studies also motivate our present work to study the empirical evidence of the liquidity effect in Canada.

Many of the early empirical studies do not find evidence of the liquidity effect. Most of the earlier econometric studies identify positive innovations in monetary aggregates or negative innovations in the short-term interest rates as expansionary money supply shocks. The traditional approach to measuring the liquidity effect, used in Cagan and Gandolfi (1969), Melvin (1983) and Cochrane (1989), is to regress the interest rate on current and past money growth.

Cagan and Gandolfi (1969) study the relationship between the commercial paper rate and M2 for the period 1910-65. They find that the paper rate reaches a trough six months after an increase in money growth. The positive impact of money on interest rates occurs only after a considerable lag. Melvin (1983) extends the analysis to include M2 data drawn from the 1970s. He finds that the liquidity effect is much shorter-lived over the 1973-79 period. The initial liquidity effect of faster money growth is likely to be offset within the month following the monetary policy change. Melvin dubs the finding "the vanishing liquidity effect" and attributes it to enhanced inflation sensitivity that causes the anticipated inflation effect of a monetary expansion to dominate the liquidity effect. High inflation rates in the 1970s may account for the reduction in the duration of the liquidity effect from that experienced in earlier decades. Cochrane (1989) subsequently finds that the liquidity effect reemerges during the 1979-82 period when the Federal Reserve targeted non-borrowed reserves, lasting at least a few months. 6

The empirical evidence presented in these earlier studies, which are based on the traditional approach, suggests that the relationship between innovations in money aggregates and interest rates varies over time and is not as persistent in some periods as the liquidity hypothesis would suggest.

6. The data used are the Monday auction average 3-month treasury bill rate and non-seasonally adjusted M1. 
Leeper and Gordon (1992) point out that the distributed lag regressions implicitly assume that no other variables induce interest rates and money growth to move together to generate the correlations estimated in the traditional approach. To explore this possibility, they estimate a fourvariable VAR that includes money growth, interest rates, consumer prices and industrial production. They study the relationship between monthly series of the monetary base and the federal funds rate over the 1954-90 period. They identify innovations in the monetary base (instead of M2, for example) as exogenous policy disturbances by arguing that the monetary base is the Federal Reserve's control variable and is more closely associated with the open market operations that underlie the liquidity effect. Two versions of the VAR are estimated, one in which money growth is exogenous and one that is completely unrestricted. The correlation between unanticipated monetary growth and the funds rate is never negative and is strongly positive in some subperiods.

Recent empirical studies of the liquidity effect by Christiano and Eichenbaum (1992a) and Strongin (1992) argue that the use of broad money aggregates such as M1 or M2 is inappropriate. These aggregates are largely influenced by the shocks in the demand for money and are not directly related to the Federal Reserve's policy action.

Christiano and Eichenbaum argue that NBR is the appropriate measure of money in studying the liquidity effect. The level of NBR is directly controlled by the Federal Open Market Committee through open market operations. Therefore, it is a suitable measure of money to use in identifying and estimating the effects of monetary policy shocks. Christiano and Eichenbaum perform VARs on monthly and quarterly data that include a measure of money, the federal funds rate, a measure of aggregate real output and the price level.

The dynamic response of the federal funds rate to a shock in monetary policy is studied using different measures of money, namely M0, M1 and NBR. When NBR is used in the analysis, the federal funds rate displays a sharp, large, persistent decline in response to expansionary policy, regardless of which identifying assumptions are used, regardless of which postwar sample period is used and regardless of whether monthly or quarterly data are used. Unanticipated expansionary policy shocks always drive down short-term interest rates and increase real output.

Strongin argues that in actual practice the Federal Reserve accommodates innovations in the demand for reserves, and he suggests that policy innovations can be identified as those changes in the mix of borrowed reserves and NBR that are not the result of the Federal Reserve's accommodation of demand innovations. Strongin's study considers monthly data from 1959:1 to 1992:2 and subsamples similar to those in Leeper and Gordon. Two sets of VARs are presented 
for each subsample. The first set is a three-variable VAR containing total reserves $(T R)$, the nonborrowed reserve mix $(N B R X)$ and the federal funds rate $(F F)$. The second set includes two more variables: the log of industrial production and the log of the consumer price index. He finds that for the entire period and for each subsample, there is a clear liquidity effect. It is always negative and highly significant.

The empirical studies for the United States show that it is important to choose an appropriate measure of money - likely NBR - for studying the liquidity effect. These studies also show that it is necessary to properly identify monetary policy shocks. In Canada, the framework for implementing monetary policy is very different from that in the United States, and there is no direct empirical counterpart to the NBR used for the measure of money in the United States. Therefore we focus our study on using excess cash as a measure of liquidity. The level of excess cash is directly influenced by the Bank of Canada through the cash setting, which in turn, influences the call loan rate. We believe that excess cash is a suitable measure of liquidity to identify and estimate the effects of monetary policy shocks. We will discuss our liquidity measures in more detail in Section 4. 


\section{Methodology: structural vector autoregression and identification}

The approach used in the present study is the structural vector autoregression (SVAR) approach employed by Bernanke (1986), Sims (1986, 1992), and Christiano and Eichenbaum (1992a). This technique allows us to use economic theory to transform the reduced-form VAR model into a system of structural equations. The SVAR yields impulse responses and variance decompositions that can be given structural interpretations. We begin this section with a brief description of the SVAR approach.

Suppose the economy evolves according to

$$
A X_{t}=C(L) X_{t-1}+\varepsilon_{t} .
$$

Here $X_{t}$ is a vector of variables summarizing the state of the economic system. In this study, we consider a six-variable VAR consisting of a measure of liquidity $(M)$, interest rate $(R)$, output $(Y)$, the price level $(P)$, exchange rate $(P F X)$ and the U.S. federal funds rate $(F F)$. The matrix $A$ is a square matrix of structural parameters on the contemporaneous endogenous variables that indicates the contemporaneous relationships in the model. $C(L)$ is a matrix polynomial in positive powers of the lag operator $L$. The structural disturbances in this economy are summarized by the identically, independently distributed random variable $\varepsilon_{t}$, which is a vector of white noise.

Equation (1) can be transformed into the following reduced form:

$$
X_{t}=\beta(L) X_{t-1}+e_{t}
$$

where $\beta(L)=A^{-1} C(L)$ and $e_{t}=A^{-1} \varepsilon_{t}$. This is a VAR representation of the structural model in (1).

The SVAR approach that we employ here imposes restrictions on $A$ and the covariance matrix of the structural shocks $\left(\Sigma_{\varepsilon}\right)$, which are both 6 by 6 matrices, to identify these structural parameters from the covariance matrix of the residuals $\left(\Sigma_{\mathrm{e}}\right) .{ }^{7}$ Specifically, $\Sigma_{\varepsilon}$ is specified as a diagonal matrix, because the primitive structural disturbances are assumed to originate from independent sources and $\Sigma_{\varepsilon}$ is further normalized to be the identity matrix. ${ }^{8}$ However, additional restrictions are still required to identify the matrix $A$. The type of restriction most relevant for the

7. This is commonly called the contemporaneous approach. For more details about SVAR and different identification approaches, see Keating (1992) and Watson (1993).

8. This is similar to the normalization restrictions used in Chamie, DeSerres and Lalonde (1994). As shown in Appendix 2, an alternative way of normalization is to set the main diagonal elements of $A$ to unity because each structural equation is normalized on a particular endogenous variable. Both ways impose additional $n$ restrictions ( $n=6$ here). 
existing liquidity literature is to put restrictions on the contemporaneous nature of feedback between the elements of $X_{t}$. One common way is to adopt a particular Wold causal interpretation of the data. The idea is to assume that the matrix $A$ is lower triangular when the variables in $X_{t}$ are ordered according to their causal priority.

When the variables in $X_{t}$ are ordered as $\{M, R, Y, P, P F X, F F\}$, they indicate that unanticipated changes in monetary policy are measured by the innovations in $M$. This view corresponds to the assumption that the contemporaneous portion of the Bank of Canada's feedback rule for setting $M_{t}$ does not involve $R_{t}, Y_{t}$ or other contemporaneous variables. The Wold ordering of $\{F F, M, R, Y, P, P F X\}$ implies that the unanticipated change in monetary policy is measured by the portion of the innovation in $M_{t}$ that is orthogonal to the innovation in $F F_{t}$. This outlook corresponds to the assumption that the contemporaneous portion of the central bank's feedback rule for setting $M_{t}$ involves $F F_{t}$, but not $R_{t}, Y_{t}$ or other contemporaneous variables.

The different identification schemes that we consider in this study are summarized in Table 1 (p. 27). The orderings that we use are very similar to those used by Christiano and Eichenbaum (1992), Eichenbaum and Evans (1993), Sims (1992) and Strongin (1992). This similarity facilitates comparison of our findings with U.S. studies.

There are basically two sets of orderings: one with $F F$ appearing first and one with $F F$ appearing last in the Wold causal chain. We consider the ordering in which the federal funds rate is first in the causal chain to be more reasonable, since the Canadian variables have little influence on the federal funds rate. However, this ordering also assumes that the Bank of Canada may take the federal funds rate into consideration when setting $M_{t}$. Alternatively, we consider ordering the federal funds rate last in the causal chain. In this case, we assume that the Bank's feedback rule for setting $M_{t}$ does not involve the federal funds rate.

Among all the orderings, we consider those in which $F F$ and $P F X$ appear first and $Y$ and $P$ appear last to be the most appropriate. The assumption that the contemporaneous portion of the Bank of Canada's feedback rule for setting monetary policy involves $F F_{t}$ and $P F X_{t}$ (or $R_{t}$, if $R_{t}$ appears before $M_{t}$ in the ordering) is consistent with the view that the Bank of Canada reacts to current financial conditions. Besides, current month values on economic variables such as $Y$ and $P$ would not be available until at least one month later. The results to be reported in Section 4, however, show that the empirical findings are robust to the different orderings used in the study.

The estimation of the SVAR proceeds as follows. First, the reduced form VAR represented in equation (2), with adequate lags of each variable, is estimated by ordinary least squares (OLS). Second, the structural parameters in $A$ and the structural disturbances are identified. Standard 
errors of the impulse response and variance decomposition functions are then calculated using a Monte Carlo simulation in order to construct their confidence bands. ${ }^{9}$

9. The Monte Carlo procedure employed here is the normal approximation procedure outlined in Doan (1990). 


\section{Empirical results}

\subsection{The data}

This section examines the dynamic responses of the variables of interest to monetary policy shocks. In deciding which variables to include in our study, we have to face the following tradeoff. In order to minimize omitted-variable bias, we would like to include as many relevant variables in our VAR system as possible. However, the set of variables must be limited, as each equation has many lags of each variable. Should the variable set become too large, the model would exhaust the available data. Therefore, the variable set chosen includes the following domestic variables: a measure of liquidity, the interest rate, output and the price level. Given the openness of the Canadian economy, we also include the Canada-U.S. nominal exchange rate and the U.S. federal funds rate. Appendix 1 provides a detailed description of the data used. The data are monthly. A six-variable VAR for each ordering is estimated in levels (except output and the consumer price index, which are in log-levels). ${ }^{10}$ Six lags of each variable are included in the VARs along with a constant term. ${ }^{11}$

\subsubsection{Liquidity measures}

We consider both excess cash and cash surprise as measures of liquidity. Excess cash reserves are chartered bank deposits at the Bank of Canada in excess of the statutory minimum. Essentially, excess cash is a measure of the supply of liquidity to the banking system. We also take excess cash to be the target policy setting of the Bank of Canada. Data on excess cash is available on a daily basis from 1977:8. In order to get the monthly observations on excess cash, that is, the total cumulative net cash positions of the chartered banks over a month, we consider two alternative

10. Unit-root tests indicate that all variables are integrated of order one or two, except for the liquidity measure variables, which are stationary. However, Sims, Stock and Watson (1990) argue that the common practice of transforming models to stationary form is unnecessary in many cases. Specifically, in "large enough" samples, the OLS estimator is consistent whether or not the VAR (in levels) contains integrated components (p. 113). Impulse response analysis relies on consistent parameter estimates. This requirement is satisfied when a VAR is estimated in levels. Similar estimations on levels were used in Christiano and Eichenbaum (1992a), Sims (1992), and Strongin (1992).

11. The Akaike Information Criterion for VAR optimal lag selection as outlined in Judge et al. (1988) gives an optimal lag length of 2 for the VAR systems. We chose to use a lag of 6 in order to capture more dynamics in the system, as monetary policy is presumed to affect the economy with a lag, as well as to be consistent with other studies. The results for the impulse response and variance decomposition functions when using a lag of 2 are qualitatively the same as those presented. However, the fluctuations are smoother and the magnitude of changes is, in some cases, different. Eichenbaum and Evans (1993) and Strongin (1992) also chose 6 lags for their analysis. Given that our sample runs from 1977:8 to 1991:10, which is slightly more than 14 years of monthly observations, there are less than two complete business cycles in this period. Therefore, in order to capture the monetary policy content of this period, a half-year lag seems appropriate. 
methods of cumulating the data: first, by calculating the average of the two end-of-period cumulative excess cash positions (EC1), and second, by taking the average of the two mid-period cumulative excess cash positions (EC2). ${ }^{12}$ Cash surprise (CS) is the cumulative total of the differences between the target policy setting of excess cash supplied by the Bank of Canada and the amount of excess cash expected by the chartered banks. ${ }^{13}$ It indicates the extent to which the Bank intends to surprise the banking system in its reserve provision, and hence measures the Bank's desire to put pressure in one direction or the other on the short-term interest rate. Graph 1a (p. 31) depicts EC1 and EC2 together, while Graph 1 b (p. 31) plots $C S$.

When $E C 1$ or $E C 2$ is used as a measure of liquidity, the regressions are run over 1977:81991:10. We begin our estimation from 1977, as the mid-period cumulative excess cash position (EC2) is available only from 1977:8. Starting in November 1991, the Bank of Canada changed its system of implementing monetary policy in anticipation of the phasing-out of reserve requirements that began in mid-1992. The calculation period became a month. In addition, the Bank of Canada started to target the settlement balances of all direct clearers in the Canadian Payments Association (CPA) rather than those of the chartered banks alone. ${ }^{14}$ Therefore, we chose to end the estimation in 1991:10 in order to maintain the consistency of the cash management system over the sample period. We consider only monthly data because of the relatively short sample period. When cash surprise is used as the liquidity measure, the regressions are run over 1987:1-1991:10, because data on the chartered banks' expectations of cash setting begin in 1987. In this system, only three lags are included due to the small sample size.

\subsubsection{Rates and macro-variables}

The relevant short-term interest rates are the call loan rate (Rcall), the 90-day commercial paper rate $(R 90)$, and the 90-day treasury bill rate (RTB90). Graphs $2 \mathrm{a}$ and $2 \mathrm{~b}$ (p. 32) plot Rcall and the Rcall - $R 90$ spread respectively. The other relevant variables that are considered in this study are

12. Donna Howard of the Bank of Canada has pointed out that the monetary policy content may be netted out if we cumulate excess cash through each calculation period. For instance, there have been averaging periods when the banks have had large negative excess reserves in the first half of an averaging period, but by the close of the averaging period they have had a large positive excess reserve as the Bank provided more cash to the system in the latter half. Therefore, we also cumulate the excess reserves to the middle of each averaging period.

13. The Bank of Canada obtains the cash targets of the direct clearers each day by direct communication; see Clinton and Howard (1994).

14. Direct clearing members of the CPA include the Bank of Canada, the six major banks and seven other large banks and non-bank deposit-taking institutions. All other institutions have clearing and settlement accounts with the direct clearers. 
output measured by industrial production $(Y)$, the consumer price index $(P)$, the nominal CanadaU.S. exchange rate $(P F X)$, and the U.S. federal funds rate $(F F)$. The interest rates and the exchange rate used are the averages of the daily observations over a month, except for RTB90, which is the end-of-month observation.

\subsection{The dynamic responses}

\subsubsection{Impulse response functions}

The impulse response function (IRF) results are reported in Figures 1 through 12 (pp. 33-44). The Wold orderings used in the estimations are given in the title of the figures. These results display the response of each variable in the system to a one-standard deviation shock in the liquidity variable. The columns correspond to each of the three liquidity measures employed in the study: $E C 1, E C 2$, and $C S$ respectively. For example, the third row of the first column in Figure 1 (p. 33) shows the dynamic response of Rcall to a one-standard deviation shock in EC1. We are most interested in the effects of an unanticipated monetary policy shock on Rcall, $Y$ and $P F X$. The solid lines in the figures represent the impulse response functions, while the dashed lines correspond to the 95 per cent upper and lower confidence bands about the point estimate of the IRF. ${ }^{15}$ A response can be thought to be significant if both bands, as well as the point estimate, lie on the same side of the zero line. (The units for the call loan rate and the federal funds rate are in percentages, so that 0.5 on the scale indicates 50 basis points, for example, and the units for the liquidity measures are in millions of dollars.)

We begin by considering the results of the VAR under a Wold causal ordering of $\{F F, M$, $R, Y, P, P F X\}$. This ordering corresponds to the assumption that the contemporaneous portion of the Bank of Canada's feedback rule for setting monetary policy involves $F F_{t}$ but not $R_{t}, Y_{t}, P_{t}$ or

$P F X_{t}{ }^{16}$ Thus, a monetary policy shock is measured by the component of the innovation in $M_{t}$ that is orthogonal to the innovation in $F F_{t}$. These results are presented in Figure 1. Responses are shown over a horizon of 48 months.

Consider first the findings when ECl is employed as the monetary policy variable. Following positive innovations to monetary policy, Rcall declines significantly and stays below its preshock level for about three months. The effects of the monetary policy shock on Rcall

15. The two standard deviation bands were computed using Monte Carlo simulations employing 1000 random draws. The reported impulse response function is the average of the 1000 Monte Carlo draws.

16. Note that no restrictions are imposed on the lagged components of the Bank of Canada's feedback rule. 
become insignificant after two months. The maximum impact of a one-standard deviation shock (approximately $\$ 450$ million) in EC1 on Rcall equals 15 basis points and occurs within two months of the monetary policy shock. Industrial production rises in the period after the shock and stays above its preshock level for over a year. The effects on industrial production are significant in the third month following the liquidity shocks. Another variable of interest is the exchange rate. The response of $P F X$ to the liquidity shock is presented in the last row. Following the monetary policy shock, the Canadian dollar depreciates slightly for about three months. However, the effects on the exchange rate are not significant. Eichenbaum and Evans (1993) also find a depreciation of the U.S. dollar after a positive liquidity shock. Their findings, though, are more significant and stable. The response of the price level to a positive liquidity shock is initially negative - but the negative response is weak and eventually becomes positive. This initial counterintuitive response of the price level can also be found in Sims (1992) and Strongin (1992). This "price puzzle" raises some difficulties for interpreting innovations in excess cash reserves as monetary policy shocks. These are considered further below.

The results for $E C 2$ are reported in the second column of Figure 1 and are quite similar to those of $E C 1$ except that the effects are now more persistent. Following the monetary policy shock, Rcall is below its preshock level for about six months, industrial production increases for almost four years, and the Canadian dollar depreciates against the U.S. dollar for close to two years. The maximum impact on Rcall equals 20 basis points and occurs immediately after the monetary policy shock. The effects of the monetary policy shocks on Rcall and $Y$ are significant for only about three months, however, while the effects on PFX are not significant. The response of the price level is again counterintuitive. Prices drop significantly for about three months and remain below the preshock level for over 48 months.

The results for $C S$, reported in column 3 in Figure 1, are mixed. Following the monetary policy shock, Rcall is below its preshock level for about nine months with a significant effect for one month. The maximum impact of a one-standard deviation shock (roughly $\$ 900$ million) to $C S$ on Rcall equals 8 basis points and occurs immediately after the monetary policy shock. Following the monetary policy shock, there is a temporary increase in industrial production, immediately followed by a decline. However, industrial production remains above its preshock level for over four years, although the effect is not significant. The response of the exchange rate is rather unstable but insignificant. This may be due to the relatively short sample period. Immediately after impact, prices drop significantly for two months and remain below the preshock level for over 48 months. 
To sum up the results in Figure 1: regardless of which liquidity measure is used in the analysis, a positive liquidity shock leads to a decline in Rcall and an increase in output. The statistical significance of the movements in Rcall and output depends on the liquidity measures used. In all cases, however, the declines in Rcall are significant for at least the first two months after impact. The increase in output is significant in the third month after impact when either ECI or $E C 2$ is used.

For all three measures of liquidity, the response of the price level poses some problems. The price level drops after the positive liquidity shock and only eventually rises above the preshock level when ECl is used. This price puzzle is also reported in Sims (1992) and Strongin (1992). Sims studies the effects of monetary policies in five countries, including France, Germany, Japan, the United States and the United Kingdom. When innovations in the interest rate are used as a measure of monetary policy innovations, all five countries display some perverse price effects initially. The positive responses of prices to positive innovations in the interest rate are strong and persistent only in France and Japan. In the other countries, the responses are weaker and eventually become negative. Strongin also reports the perverse price effect: following a positive innovation in $N B R X$, the price level drops significantly for about eight months and only rises above the preshock level after about 30 months.

Sims suggests that the perverse price effect may reflect the fact that the monetary authority has some indicator of inflation in its reaction function that is missing from the VAR underlying the monetary policy shock measures. Therefore, he includes a measure of commodity prices in the VAR as a proxy for inflationary pressure and finds that the price responses are somewhat improved. Christiano, Eichenbaum and Evans (1994) find that by including commodity prices in the VAR, the responses of prices are no longer anomalous when either innovations in the federal funds rate or NBR is used as a measure of monetary policy shocks.

In results not reported here, we find no perverse price effect when innovations in Rcall are used to measure monetary policy shocks. Following a positive shock in Rcall, the price level drops and always remains below the preshock level, although the response is not statistically significant. However, as shown above, the price response is counterintuitive when excess cash reserves are used. Unlike Christiano, Eichenbaum and Evans (1994), we have been unable to resolve the price puzzle in our study by including either the commodity price index or the termsof-trade index. ${ }^{17}$

17. The commodity price index used is the Bank of Canada commodity price index. The terms-of-trade index used is the ratio of the price of Canadian commodities to the price of U.S. manufactured goods. 
The results of the VAR reported above are robust to different Wold orderings. The results for the remaining 11 orderings are shown in Figures 2 to 12 (pp. 34-44). For all measures of liquidity used in this study, unanticipated expansionary monetary shocks lead to significant declines in the call loan rates and significant increases in output, regardless of the ordering used in the VAR. However, the persistence of such effects varies among different measures of liquidity. The declines in the call loan rate range from three months when $E C l$ is used as the measure of liquidity to about one year when $C S$ is used. Output increases for about 15 months when $E C l$ is used as the measure of liquidity and increases over the 48-month horizon when $E C 2$ is used. When $C S$ is used, the response of output is rather unstable and sensitive to the orderings. The statistical significance of these responses depends on the ordering of the VAR estimation. For all orderings, the declines in Rcall are rarely significant after three months when $E C l$ or $E C 2$ is used and are not significant after six months when $C S$ is used. For all orderings, the increases in output are not significant after three months when $E C 1$ or $E C 2$ is used, and the responses of output are never significant when $C S$ is used.

These findings are consistent with similar studies in the United States and support the presence of liquidity effects in Canada. An unanticipated expansionary monetary policy lowers the interest rate, stimulates output and leads to a depreciation of the Canadian dollar. These results are consistent with the operation of monetary policy by the Bank of Canada and support the view that the Bank of Canada can influence the call loan rate by affecting the level of excess cash reserves of the chartered banks.

\subsubsection{Variance decompositions}

Finally, we briefly turn to the overall contribution of monetary policy shocks to the variability of other variables. We compute the percentage of the variance of the $j$-step ahead forecast error of each variable that is attributable to monetary policy shocks. Tables 3 through 5 (pp. 28-29) report the variance decomposition functions (VDF) of each measure of liquidity over different horizons for the ordering of $\{F F, M, R, Y, P, P F X\}$ with the 95 per cent confidence bands about the VDF point estimates. ${ }^{18} \mathrm{~A}$ significant effect is judged by a non-zero lower 95 per cent confidence band. The estimated percentages for $E C l$ or $E C 2$ are not very high and are not significant. About 1.9 per cent (after 1 month) to 6.6 per cent (after 48 months) of variance in Rcall can be explained by innovations in $E C 1$. The percentages of explained variance by innovations in $E C 2$ are slightly higher. For example, about 4.5 per cent to 8.4 per cent of the forecast error of Rcall can be

18. The confidence bands were computed using Monte Carlo simulations employing 1000 random draws. The reported variance decomposition function is the average of the 1000 Monte Carlo draws. 
explained by innovations in $E C 2$. The VDFs for $C S$ are reported in Table 5 (p. 29) and the estimated percentages are higher than those for $E C 1$ or $E C 2$. About 11.4 per cent of the forecast error variance of $Y$ can be accounted for significantly by innovations in $C S$, whereas 11.7 per cent of the forecast error variance in $P F X$ can be explained by the innovations in $C S$, with the results also being significant for over a year. The VDFs for each measure of liquidity are similar for different orderings of the VAR estimation, except for $C S$. Therefore, we report only the VDFs for one additional ordering of $\{F F, Y, P, M, R, P F X\}$ in Tables 6 through 8 (pp. 29-30). As can be seen in Table 8, about 19 to 24 per cent of the forecast error variance of Rcall can be explained by the innovations in $C S$, and the results are significant for over two years. Similar results can be found in orderings (4), (10) and (12) from Table 1 (p. 27) (results are not reported in the paper). Despite the insignificant variance decomposition functions, the impulse response functions for Rcall and $Y$ are significant from three to six months for all measures of liquidity.

\subsection{Sensitivity analysis}

In this subsection, we reexamine the VAR results in the previous subsection using different sample periods and different measures of interest rates.

\subsubsection{Sample period sensitivity tests}

Here we examine the dynamic responses of the variables of interest to a liquidity shock over different sample periods. Since ECl is available from 1971:6, we reestimate the VAR model with the ordering $\{F F, M, R, Y, P, P F X\}$ over the period 1971:6 to 1991:10. The dynamic responses of Rcall, $Y$ and $P F X$ to a one-standard deviation shock in $E C l$ are graphed in Figure 13 (p. 45) and are very similar to those reported in Figure 1. The output effect, however, has become marginally insignificant.

We also examine this VAR system over the period 1971:6 to 1994:1, and the impulse response functions are graphed in Figure 13 (p. 45). A liquidity shock causes Rcall to decline for about three months but the effect is now insignificant. Industrial production rises after the liquidity shock and stays above its preshock level for over two years. The effects, however, are not significant. The results are different from the estimations that include data only up to 1991:10. We also extend the sample period for $C S$ to 1994:1 and reexamine the model's dynamic responses. Following a liquidity shock, Rcall declines for about nine months but the effect is not significant, and output increases for almost a year but the effect is only significant for about two months. As explained in subsection 4.1 .1 (p. 10), there was a change in the system of implementation of monetary policy in November 1991. The results reported here suggest that the 
change in procedure has lessened the ability of the VAR to detect liquidity effects over the full sample period 1971 to 1994.

\subsubsection{Sensitivity with respect to different measures of interest rates}

The VAR estimations are also repeated using different measures of interest rates, namely, the 3-month treasury bill rate $(R T B 90)$ and the 3-month commercial paper rate (R90), instead of Rcall. The impulse response functions for the ordering of $\{F F, M, R, Y, P, P F X\}$ with $R T B 90$ and $R 90$ are reported in Figures 14 and 15 (pp. 46-47) respectively.

When $R T B 90$ is used, the dynamic responses of the variables in the VAR become more sensitive to the Wold causal ordering for all three liquidity measures. We can still find some significant negative interest rate responses to a liquidity shock. However, for some orderings, the responses of $R T B 90$ are positive in the period after a positive liquidity shock. RTB90 stays above the preshock level for a few months but the effects are insignificant. For all three liquidity measures, the output effect of a positive liquidity shock is positive but is not significant. Following a positive innovation in $E C 1$ or $E C 2$, output rises for about four months to a year. The output effects of a positive shock in $C S$ are very similar to the case where Rcall is used as the interest rate; that is, the effects are positive for almost four years. The dynamic responses of $P F X$ and $P$ are not too sensitive to the use of $R T B 90$ as the interest rate, except that for most Wold orderings the immediate response of $P F X$ to a liquidity shock is an appreciation in the Canadian dollar. Again, this effect is not significant.

The IRFs for the VAR with $R 90$ are very similar to those with $R T B 90$. However, when $E C 1$ or $E C 2$ is used as the liquidity measure, $R 90$ rises immediately after the shock and the effects are significant for some orderings. The positive interest rate effects are hardly significant beyond two months after impact. The output effect of a shock in $E C 2$ is positive and significant within about three months of impact.

\subsubsection{Summary}

The main results in our study seem to be robust to different sample periods, although the change in the monetary policy implementation procedures in 1991 and 1992 seem to have lessened the ability of the VAR to detect liquidity effects over 1971 to 1994 . The results, however, are more sensitive to the uses of different interest rates. When Rcall is used, the findings support the presence of liquidity effects in Canada. In comparison with $R T B 90$ or $R 90$, the evidence of liquidity effects becomes less obvious and depends on the ordering of the VAR estimation. This is consistent with the view that the Bank of Canada has a large influence on Rcall through the cash setting but has 
only an indirect influence on $R T B 90$ and $R 90$; both $R T B 90$ and $R 90$ are mainly determined by money market conditions. 


\section{Concluding remarks}

In this paper, we have studied the effects of a liquidity shock on the interest rate, output and the exchange rate. The measures of liquidity that we have used in the study are the excess cash reserves of the chartered banks. Since the Bank of Canada has direct control of excess cash through its daily cash setting, it is a suitable measure of the Bank's monetary policy actions. The major findings of our study can be summarized as follows: we find that expansionary shocks to monetary policy are followed by declines in the interest rates, an increase in output, and a depreciation of the Canadian dollar. The results are robust to different orderings of the variables used in the VAR estimation. The responses of interest rates to monetary policy shocks are robust to different measures of liquidity, but the responses of other variables vary slightly.

The present study provides empirical evidence of liquidity effects in Canada. Looking ahead, we believe it would be worthwhile to extend the present analysis by employing different identification restrictions. Instead of restricting the contemporaneous matrix $(A)$ to be lower triangular, one could impose more realistic restrictions on $A$. For example, one can restrict $A$ by using the fact that monetary policy reacts to the monetary conditions index, thus specifying the contemporaneous response of $M$ to a linear combination of $R$ and $P F X$. This kind of modification may provide better identification of monetary policy shocks. Finally, it would be of interest and of importance to construct a liquidity-effect model that reflects the Canadian institutional context and in which both money and credit play important roles in the transmission of monetary policy. Ultimately, such a model might be able to provide a useful theoretical framework for thinking about monetary policy in Canada. 



\section{Appendix 1: Description of the data}

Here the data used in the study are outlined. All the data are of a monthly frequency, except where noted (for example, excess cash). The interest rates and the exchange rate are the averages of daily observations over a month, except for $R T B 90$, which is the end-of-month observation.

\section{Money (M):}

- Excess cash $(E C)$ - Excess cash reserves are chartered bank deposits at the Bank of Canada in excess of the statutory minimum. The monthly series is constructed from daily excess cash by cumulating the daily data over each averaging period. Two alternative methods of cumulating the data are considered: first, by calculating the average of the two end-of-period cumulative excess cash positions (EC1), and second, by taking the average of the two mid-period cumulative excess cash positions (EC2). The end-of-period cumulation data is available from 1970:1 to 1994:3, while the midperiod data are available from 1977:8 to 1994:3.

- Cash surprise $(C S)$ - Cash surprise is the difference between the target policy setting of excess cash reserves in the chartered banks and the setting that the chartered banks expect to have attained as a result of their money market operations. The monthly series is constructed by cumulating the daily cash surprise over the averaging period. This series is available from 1987:1 to 1993:12.

\section{Interest rates $(R)$ :}

- Call loan rate (Rcall) - Special call loans are loans made to money market dealers for a short period of time to finance their inventory of money market securities. They were first introduced by the chartered banks in 1967 and subsequently became the most important source of dealer financing from the chartered banks. Both reduced system liquidity (a tight policy) and the building of inventory by dealers will put upward pressure on the call loan rate. The series is available in the CANSIM data base from 1975. However, daily high and low Rcall is available in the data base at the Bank of Canada from June 1971. An average of the daily high and low call loan rates from June 1971 to December 1974 can be added to Rcall to extend the series backwards. Thus Rcall is available from 1971:6 to 1994:4.

- 90-day treasury bill rate $(R T B 90)$ - available from 1935.

- 90-day commercial paper rate (R90) - available from 1956.

\section{Output (Y):}

- Industrial production - Data in constant 1986 dollars are available on a monthly basis from 1961:1 to $1994: 1$.

\section{Prices $(P)$ :}

- CPI - available from 1914:1 to 1994:3 . 


\section{Canada-U.S. nominal (spot) exchange rate $(P F X)$ :}

- $\quad P F X$ is the U.S. dollar exchange rate prevailing on the interbank market at noon, Ottawa time. An increase in the rate implies depreciation of the Canadian dollar.

- Data are available from 1970:1 to 1994:4.

\section{U.S. federal funds rate $(F F)$ :}

- Data are available from 1954:1 to 1994:3. 


\section{Appendix 2: Identification of the structural VAR}

This appendix describes the identification of the structural VAR under the contemporaneous approach similar to the one used in Christiano and Eichenbaum (1992a). The notation used is the same as that used in Section 3.

Suppose the economy evolves according to

$$
A X_{t}=C(L) X_{t-1}+\varepsilon_{t}
$$

It can be transformed into the following reduced form:

$$
X_{t}=\beta(L) X_{t-1}+e_{t},
$$

where $\beta(L)=A^{-1} C(L)$ and $e_{t}=A^{-1} \varepsilon_{t}$. Thus the covariance matrix for the reduced-form residuals $e_{t}$ is related to that of the structural shocks $\varepsilon_{t}$ in the following relation:

$$
\Sigma_{e}=E\left[e_{t} e^{\prime}{ }_{t}\right]=A^{-1} E\left[\varepsilon_{t} \varepsilon_{t}^{\prime}\right] A^{\prime-1}=A^{-1} \Sigma_{\varepsilon} A^{\prime-1}
$$

By estimating the reduced-form VAR in (A2.2) by OLS, we can obtain estimates for the $\beta$ 's and $\Sigma_{\mathrm{e}}$, which has $n(n+1) / 2$ unique elements. However, we need to know $A$ first in order to identify the structural shocks $\varepsilon$ from the reduced-form residuals $e$. It can easily be seen from (A2.3) that we need additional restrictions to recover both $A$ and $\Sigma_{\varepsilon}$. This can be achieved by imposing theoretical restrictions to reduce the number of unknown structural parameters in $A$ to be less than or equal to the number of estimated parameters of the covariance matrix of the VAR residuals.

The contemporaneous approach imposes restrictions on these two matrices: the coefficient matrix $A$ with $n^{2}$ elements and the symmetric structural covariance matrix $\Sigma_{\varepsilon}$ with $n(n+1) / 2$ unique elements. ${ }^{1}$ At least $n^{2}$ restrictions have to be imposed on $A$ and $\Sigma_{\varepsilon}$ to get the structural models identified. First, $\Sigma_{\varepsilon}$ is specified as a diagonal matrix, because the primitive structural disturbances are assumed to originate from independent sources, thus imposing $n(n-1) / 2$ restrictions. Second, $n$ restrictions are imposed by normalization. This can be done in two different ways. One way is to set the main diagonal elements of $A$ to unity as each structural equation is normalized on a particular endogenous variable. As one endogenous variable in each structural equation is usually regarded as the dependent variable, its coefficient can be arbitrarily

1. An alternative structural VAR method, developed by Shapiro and Watson (1988) and Blanchard and Quah (1989), uses long-run restrictions to identify the economic structure from the reduced form. For our purposes, however, the contemporaneous approach seems more relevant. 
set at unity. Alternatively, we can normalize each diagonal element of the covariance matrix $\Sigma_{\varepsilon}$ to unity. This is the method we use in this study. In other words, $\Sigma_{\varepsilon}$ is now an $n$ by $n$ identity matrix. Only $n(n-1) / 2$ additional restrictions are required. One simple way to impose these restrictions is to make $A$ a lower triangular matrix; this implies $n(n-1) / 2$ exclusion restrictions on $A$. In sum, there are $n(n+1) / 2$ elements in $\Sigma_{\mathrm{e}}$ to be used in identifying the $n(n+1) / 2$ elements in $A$. Thus $A$ can be identified and used to calculate $C(L)$ and the structural disturbance $\varepsilon$. In this case, we have an exactly identifiable system.

By normalizing $\Sigma_{\varepsilon}$ to be the identity matrix, (A2.3) can be written as

$$
\Sigma_{e}=A^{-1} A^{\prime-1}
$$

Given that $A$ is a triangular matrix, we can use the Choleski decomposition to solve for the elements of $A$ from $\Sigma_{\mathrm{e}}$.

After the structural parameters are identified, impulse responses and variance decompositions are used to summarize the dynamic responses of the variables to the structural shocks, $\varepsilon_{t}$, which are known as the moving-average representation. The impulse response functions can be represented by the following equation:

$$
X_{t}=[I-\beta(L) L]^{-1} A^{-1} \varepsilon_{t}
$$

Thus

$$
X_{t}=\theta(L) \varepsilon_{t}=\sum_{i=0}^{\infty} \theta_{i} L^{i} \varepsilon_{t}
$$

where each $\theta_{\mathrm{i}}$ is an $n \times n$ matrix of parameters from the structural model and measures the response of $X_{t+i}$ to $\varepsilon_{t}$. The sequence of $\theta_{i}$ from $\mathrm{i}=0,1,2, \ldots$ illustrates the dynamic response of the variables to the shocks $\varepsilon_{t}$, that is, a unit change in $\varepsilon_{t}$ causes $X_{t}$ to change by $\theta_{o}$ and $X_{t+1}$ to change by $\theta_{l}$.

Variance decompositions measure the fraction of each variable's forecast error variance that is attributed to the individual shocks. These statistics measure the quantitative effect that the shocks have on the variables. If $\mathrm{E}_{t-j} X_{t}$ is the expected value of $\mathrm{X}_{\mathrm{t}}$ based on all information available at time $t-j$, the forecast error is 


$$
X-E_{t-j} X_{t}=\sum_{i=0}^{j-1} \theta_{i} \varepsilon_{t-i}
$$

Since the information at time $t-j$ includes all $\varepsilon$ occurring at or before time $t-j$, the forecast error for $X_{t}$, at $t-j$ is thus zero. The conditional expectation of future $\varepsilon$ is zero because all shocks are serially uncorrelated.The forecast error variances for the individual series are the diagonal elements in the following matrix:

$$
E\left(X-E_{t-j} X_{t}\right)\left(X-E_{t-j} X_{t}\right)=\sum_{i=0}^{j-1} \theta_{i} \Sigma_{\varepsilon} \theta_{i}^{\prime}
$$

If $\theta_{i v s}$ is the $(v, s)$ element in $\theta_{i}$ and $\sigma_{\mathrm{s}}$ is the standard deviation for disturbance $s(s=1, \ldots, n)$, then the $\mathrm{j}$-steps-ahead forecast variance of the $v$ th variable is:

$$
E\left(X_{v t}-E_{t-j} X_{v t}\right)^{2}=\sum_{i=0}^{j-1} \sum_{s=1}^{n} \theta_{i v s}^{2} \sigma_{s}^{2},
$$

where $v=1,2, \ldots, n$.

The variance decomposition function writes the $\mathrm{j}$-steps-ahead percentage of forecast error variance for variable $v$ attributable to the $k$ th shock:

$$
V D F(v, k, j)=\frac{\sum_{i=0}^{j-1} \theta_{i v k}^{2} \sigma_{k}^{2}}{\sum_{i=0}^{j-1} \sum_{s=1}^{n} \theta_{i v s}^{2} \sigma_{s}^{2}} \times 100 .
$$



Table 1. Ordering of the VAR estimation

\begin{tabular}{|c|c|c|c|}
\hline Ordering & FF first & Ordering & FF last \\
\hline$(1)$ & $\{F F, M, R, Y, P, P F X\}$ & $(7)$ & $\{M, R, Y, P, P F X, F F\}$ \\
$(2)$ & $\{F F, R, M, Y, P, P F X\}$ & $(8)$ & $\{R, M, Y, P, P F X, F F\}$ \\
$(3)$ & $\{F F, Y, M, R, P, P F X\}$ & $(9)$ & $\{Y, M, R, P, P F X, F F\}$ \\
$(4)$ & $\{F F, P, M, R, Y, P F X\}$ & $(10)$ & $\{P, M, R, Y, P F X, F F\}$ \\
$(5)$ & $\{F F, P F X, M, R, Y, P\}$ & $(11)$ & $\{P F X, M, R, Y, P, F F\}$ \\
$(6)$ & $\{F F, Y, P, M, R, P F X\}$ & $(12)$ & $\{Y, P, M, R, P F X, F F\}$ \\
\hline
\end{tabular}

Table 2. Variance-covariance matrices for VAR innovations

\begin{tabular}{|c|c|c|c|c|c|}
\hline$F F$ & $M$ & Rcall & $Y$ & $\boldsymbol{P}$ & $P F X$ \\
\hline \multicolumn{6}{|l|}{$E C 1$} \\
\hline \multicolumn{6}{|l|}{$0.76 \mathrm{e}-4$} \\
\hline 0.73 & 127798.30 & & & & \\
\hline $0.25 e-5$ & -0.24 & $0.46 \mathrm{e}-4$ & & & \\
\hline $0.95 e-5$ & 0.22 & $-0.11 \mathrm{e}-4$ & $0.77 \mathrm{e}-4$ & & \\
\hline $0.89 \mathrm{e}-6$ & $-0.76 \mathrm{e}-1$ & $0.18 \mathrm{e}-5$ & $-0.14 e-5$ & $0.88 \mathrm{e}-5$ & \\
\hline $0.17 \mathrm{e}-4$ & 0.37 & $-0.28 e-5$ & $-0.76 e-5$ & $-0.11 e-5$ & $0.11 \mathrm{e}-3$ \\
\hline \multicolumn{6}{|l|}{$E C 2$} \\
\hline \multicolumn{6}{|l|}{$0.77 \mathrm{e}-4$} \\
\hline 1.00 & 167022.90 & & & & \\
\hline $0.22 \mathrm{e}-5$ & -0.62 & $0.46 \mathrm{e}-4$ & & & \\
\hline $0.12 \mathrm{e}-4$ & 0.51 & $-0.11 \mathrm{e}-4$ & $0.81 \mathrm{e}-4$ & & \\
\hline$-0.22 \mathrm{e}-6$ & -0.23 & $-0.33 e-5$ & $-0.43 e-5$ & $0.92 \mathrm{e}-5$ & \\
\hline $0.16 \mathrm{e}-4$ & 0.59 & $-0.33 e-5$ & $-0.40 e-5$ & $-0.21 e-5$ & $0.11 \mathrm{e}-3$ \\
\hline \multicolumn{6}{|l|}{$C S$} \\
\hline \multicolumn{6}{|l|}{$0.35 e-5$} \\
\hline-0.29 & 760816.90 & & & & \\
\hline $0.81 \mathrm{e}-6$ & -0.75 & $0.59 \mathrm{e}-5$ & & & \\
\hline $0.18 e-5$ & 0.43 & $0.22 \mathrm{e}-5$ & $0.38 \mathrm{e}-4$ & & \\
\hline $0.21 \mathrm{e}-6$ & -1.50 & $0.61 \mathrm{e}-6$ & $-0.56 e-5$ & $0.11 \mathrm{e}-4$ & \\
\hline$-0.12 e-6$ & -1.19 & $0.24 \mathrm{e}-5$ & $-0.92 e-5$ & $0.54 \mathrm{e}-5$ & $0.55 \mathrm{e}-4$ \\
\hline
\end{tabular}

Note: The variables are ordered according to their causal orderings. 
Table 3: Variance decomposition function - ECI

$\{F F, M, R, Y, P, P F X\}$

\begin{tabular}{|c|c|c|c|c|}
\hline \multirow{2}{*}{$\begin{array}{l}\text { Horizon } \\
\text { (months) }\end{array}$} & \multicolumn{4}{|c|}{ Percentage of explained variance by innovations in $E C 1$} \\
\hline & Rcall & $Y$ & $P$ & $P F X$ \\
\hline 1 & $\begin{array}{c}1.89 \\
(0.00,5.46)\end{array}$ & $\begin{array}{c}0.81 \\
(0.00,2.96)\end{array}$ & $\begin{array}{c}1.46 \\
(0.00,4.75)\end{array}$ & $\begin{array}{c}0.84 \\
(0.00,2.96)\end{array}$ \\
\hline 6 & $\begin{array}{c}2.52 \\
(0.00,5.63)\end{array}$ & $\begin{array}{c}4.01 \\
(0.00,10.87)\end{array}$ & $\begin{array}{c}3.04 \\
(0.00,8.47)\end{array}$ & $\begin{array}{c}1.65 \\
(0.00,4.85)\end{array}$ \\
\hline 12 & $\begin{array}{c}3.46 \\
(0.00,8.92)\end{array}$ & $\begin{array}{c}4.65 \\
(0.00,13.17)\end{array}$ & $\begin{array}{c}3.60 \\
(0.00,11.23)\end{array}$ & $\begin{array}{c}2.91 \\
(0.00,8.88)\end{array}$ \\
\hline 24 & $\begin{array}{c}5.13 \\
(0.00,15.12)\end{array}$ & $\begin{array}{c}5.07 \\
(0.00,13.48)\end{array}$ & $\begin{array}{c}3.80 \\
(0.00,12.57)\end{array}$ & $\begin{array}{c}5.24 \\
(0.00,17.19)\end{array}$ \\
\hline 36 & $\begin{array}{c}6.23 \\
(0.00,18.45)\end{array}$ & $\begin{array}{c}5.90 \\
(0.00,15.94)\end{array}$ & $\begin{array}{c}4.84 \\
(0.00,16.19)\end{array}$ & $\begin{array}{c}6.55 \\
(0.00,21.76)\end{array}$ \\
\hline 48 & $\begin{array}{c}6.56 \\
(0.00,19.48)\end{array}$ & $\begin{array}{c}6.94 \\
(0.00,19.24)\end{array}$ & $\begin{array}{c}5.85 \\
(0.00,19.78)\end{array}$ & $\begin{array}{c}7.19 \\
(0.00,24.00)\end{array}$ \\
\hline
\end{tabular}

Note: $95 \%$ confidence band in parentheses.

Table 4: Variance decomposition function - EC2

$\{F F, M, R, Y, P, P F X\}$

\begin{tabular}{|c|c|c|c|c|}
\hline \multirow{2}{*}{$\begin{array}{c}\text { Horizon } \\
\text { (months) }\end{array}$} & \multicolumn{4}{|c|}{ Percentage of explained variance by innovations in $E C 2$} \\
\cline { 2 - 5 } & Rcall & $Y$ & $P$ & $P F X$ \\
\hline 1 & 8.37 & 1.68 & 4.36 & 1.38 \\
& $(0.06,16.69)$ & $(0.00,5.41)$ & $(0.00,10.24)$ & $(0.00,4.28)$ \\
\hline 6 & 4.53 & 4.46 & 6.98 & 2.08 \\
& $(0.00,9.26)$ & $(0.00,12.07)$ & $(0.00,16.68)$ & $(0.00,6.31)$ \\
\hline 12 & 5.04 & 4.83 & 6.45 & 3.32 \\
& $(0.00,11.52)$ & $(0.00,14.28)$ & $(0.00,18.00)$ & $(0.00,10.62)$ \\
\hline 24 & 6.17 & 5.48 & 6.23 & 4.42 \\
& $(0.00,16.61)$ & $(0.00,15.14)$ & $(0.00,19.54)$ & $(0.00,14.82)$ \\
\hline 36 & 6.48 & 6.17 & 6.54 & 4.95 \\
& $(0.00,17.54)$ & $(0.00,16.66)$ & $(0.00,21.13)$ & $(0.00,16.65)$ \\
\hline 48 & 6.52 & 6.49 & 6.70 & 5.25 \\
& $(0.00,17.53)$ & $(0.00,17.67)$ & $(0.00,21.73)$ & $(0.00,17.59)$ \\
\hline
\end{tabular}

Note: $95 \%$ confidence band in parentheses. 
Table 5: Variance decomposition function - CS

$\{F F, M, R, Y, P, P F X\}$

\begin{tabular}{|c|c|c|c|c|}
\hline \multirow{2}{*}{$\begin{array}{l}\text { Horizon } \\
\text { (months) }\end{array}$} & \multicolumn{4}{|c|}{ Percentage of explained variance by innovations in $C S$} \\
\hline & Rcall & $Y$ & $P$ & $P F X$ \\
\hline 1 & $\begin{array}{c}4.30 \\
(0.00,13.61)\end{array}$ & $\begin{array}{c}2.05 \\
(0.00,7.53)\end{array}$ & $\begin{array}{c}10.50 \\
(0.00,25.39)\end{array}$ & $\begin{array}{c}16.49 \\
(0.07,32.91)\end{array}$ \\
\hline 6 & $\begin{array}{c}14.35 \\
(0.00,33.53)\end{array}$ & $\begin{array}{c}7.83 \\
(0.00,18.33)\end{array}$ & $\begin{array}{c}6.91 \\
(0.00,15.14)\end{array}$ & $\begin{array}{c}11.90 \\
(1.89,21.92)\end{array}$ \\
\hline 12 & $\begin{array}{c}11.25 \\
(0.00,28.59)\end{array}$ & $\begin{array}{c}11.39 \\
(0.04,22.73)\end{array}$ & $\begin{array}{c}7.38 \\
(0.00,16.34)\end{array}$ & $\begin{array}{c}11.70 \\
(1.14,22.27)\end{array}$ \\
\hline 24 & $\begin{array}{c}11.10 \\
(0.00,26.85)\end{array}$ & $\begin{array}{c}12.37 \\
(0.00,25.02)\end{array}$ & $\begin{array}{c}11.39 \\
(0.00,24.25)\end{array}$ & $\begin{array}{c}12.34 \\
(0.05,24.62)\end{array}$ \\
\hline 36 & $\begin{array}{c}10.90 \\
(0.00,26.59)\end{array}$ & $\begin{array}{c}12.88 \\
(0.00,28.22)\end{array}$ & $\begin{array}{c}11.06 \\
(0.00,24.70)\end{array}$ & $\begin{array}{c}12.71 \\
(0.00,27.69)\end{array}$ \\
\hline 48 & $\begin{array}{c}10.92 \\
(0.00,27.32)\end{array}$ & $\begin{array}{c}12.99 \\
(0.00,30.43)\end{array}$ & $\begin{array}{c}11.51 \\
(0.00,27.61)\end{array}$ & $\begin{array}{c}13.24 \\
(0.00,30.80)\end{array}$ \\
\hline
\end{tabular}

Note: $95 \%$ confidence band in parentheses.

Table 6: Variance decomposition function - EC1

$\{F F, Y, P, M, R, P F X\}$

\begin{tabular}{|c|c|c|c|c|}
\hline \multirow{2}{*}{$\begin{array}{l}\text { Horizon } \\
\text { (months) }\end{array}$} & \multicolumn{4}{|c|}{ Percentage of explained variance by innovations in $E C 1$} \\
\hline & Rcall & $Y$ & $P$ & $P F X$ \\
\hline 1 & $\begin{array}{c}1.54 \\
(0.00,4.74)\end{array}$ & $\begin{array}{c}0.00 \\
(0.00,0.00)\end{array}$ & $\begin{array}{c}0.00 \\
(0.00,0.00)\end{array}$ & $\begin{array}{c}0.80 \\
(0.00,2.77)\end{array}$ \\
\hline 6 & $\begin{array}{c}2.29 \\
(0.00,5.30)\end{array}$ & $\begin{array}{c}2.50 \\
(0.00,7.00)\end{array}$ & $\begin{array}{c}1.50 \\
(0.00,3.76)\end{array}$ & $\begin{array}{c}1.78 \\
(0.00,5.38)\end{array}$ \\
\hline 12 & $\begin{array}{c}3.23 \\
(0.00,8.37)\end{array}$ & $\begin{array}{c}3.48 \\
(0.00,10.91)\end{array}$ & $\begin{array}{c}2.31 \\
(0.00,7.21)\end{array}$ & $\begin{array}{c}3.14 \\
(0.00,9.77)\end{array}$ \\
\hline 24 & $\begin{array}{c}5.08 \\
(0.00,15.40)\end{array}$ & $\begin{array}{c}4.66 \\
(0.00,13.52)\end{array}$ & $\begin{array}{c}3.48 \\
(0.00,11.87)\end{array}$ & $\begin{array}{c}5.58 \\
(0.00,18.66)\end{array}$ \\
\hline 36 & $\begin{array}{c}6.39 \\
(0.00,19.81)\end{array}$ & $\begin{array}{c}5.70 \\
(0.00,16.31)\end{array}$ & $\begin{array}{c}4.86 \\
(0.00,16.67)\end{array}$ & $\begin{array}{c}6.91 \\
(0.00,23.39)\end{array}$ \\
\hline 48 & $\begin{array}{c}6.78 \\
(0.00,21.08)\end{array}$ & $\begin{array}{c}6.79 \\
(0.00,19.67)\end{array}$ & $\begin{array}{c}6.00 \\
(0.00,20.39)\end{array}$ & $\begin{array}{c}7.5 \\
(0.00,25.68)\end{array}$ \\
\hline
\end{tabular}

Note: $95 \%$ confidence band in parentheses. 
Table 7: Variance decomposition function - EC2

$\{F F, Y, P, M, R, P F X\}$

\begin{tabular}{|c|c|c|c|c|}
\hline \multirow{2}{*}{$\begin{array}{l}\text { Horizon } \\
\text { (months) }\end{array}$} & \multicolumn{4}{|c|}{ Percentage of explained variance by innovations in $E C 1$} \\
\hline & Rcall & $Y$ & $P$ & $P F X$ \\
\hline 1 & $\begin{array}{c}5.15 \\
(0.00,11.11)\end{array}$ & $\begin{array}{c}0.00 \\
(0.00,0.00)\end{array}$ & $\begin{array}{c}0.00 \\
(0.00,0.00)\end{array}$ & $\begin{array}{c}1.27 \\
(0.00,4.17)\end{array}$ \\
\hline 6 & $\begin{array}{c}4.06 \\
(0.00,8.85)\end{array}$ & $\begin{array}{c}2.01 \\
(0.00,5.84)\end{array}$ & $\begin{array}{c}2.18 \\
(0.00,5.62)\end{array}$ & $\begin{array}{c}2.14 \\
(0.00,6.62)\end{array}$ \\
\hline 12 & $\begin{array}{c}4.62 \\
(0.00,10.74)\end{array}$ & $\begin{array}{c}3.10 \\
(0.00,9.81)\end{array}$ & $\begin{array}{c}2.87 \\
(0.00,9.00)\end{array}$ & $\begin{array}{c}3.32 \\
(0.00,10.74)\end{array}$ \\
\hline 24 & $\begin{array}{c}5.71 \\
(0.00,15.31)\end{array}$ & $\begin{array}{c}4.49 \\
(0.00,13.27)\end{array}$ & $\begin{array}{c}3.90 \\
(0.00,13.21)\end{array}$ & $\begin{array}{c}4.37 \\
(0.00,15.00)\end{array}$ \\
\hline 36 & $\begin{array}{c}6.06 \\
(0.00,16.49)\end{array}$ & $\begin{array}{c}5.50 \\
(0.00,15.28)\end{array}$ & $\begin{array}{c}4.77 \\
(0.00,16.41)\end{array}$ & $\begin{array}{c}4.84 \\
(0.00,16.72)\end{array}$ \\
\hline 48 & $\begin{array}{c}6.07 \\
(0.00,16.42)\end{array}$ & $\begin{array}{c}5.92 \\
(0.00,16.49)\end{array}$ & $\begin{array}{c}5.25 \\
(0.00,18.12)\end{array}$ & $\begin{array}{c}5.12 \\
(0.00,17.6)\end{array}$ \\
\hline
\end{tabular}

Note: $95 \%$ confidence band in parentheses.

Table 8: Variance decomposition function - CS

$\{F F, Y, P, M, R, P F X\}$

\begin{tabular}{|c|c|c|c|c|}
\hline \multirow{2}{*}{$\begin{array}{l}\text { Horizon } \\
\text { (months) }\end{array}$} & \multicolumn{4}{|c|}{ Percentage of explained variance by innovations in $C S$} \\
\hline & Rcall & $Y$ & $P$ & $P F X$ \\
\hline 1 & $\begin{array}{c}3.06 \\
(0.00,9.82)\end{array}$ & $\begin{array}{c}0.00 \\
(0.00,0.00)\end{array}$ & $\begin{array}{c}0.00 \\
(0.00,0.00)\end{array}$ & $\begin{array}{c}14.22 \\
(0.00,28.73)\end{array}$ \\
\hline 6 & $\begin{array}{c}23.89 \\
(3.97,43.80)\end{array}$ & $\begin{array}{c}9.09 \\
(0.00,19.12)\end{array}$ & $\begin{array}{c}8.32 \\
(0.00,18.39)\end{array}$ & $\begin{array}{c}12.26 \\
(1.38,23.14)\end{array}$ \\
\hline 12 & $\begin{array}{c}19.74 \\
(0.02,39.46)\end{array}$ & $\begin{array}{c}13.02 \\
(2.14,23.91)\end{array}$ & $\begin{array}{c}8.91 \\
(0.00,19.27)\end{array}$ & $\begin{array}{c}14.36 \\
(2.78,25.94)\end{array}$ \\
\hline 24 & $\begin{array}{c}19.07 \\
(0.22,37.92)\end{array}$ & $\begin{array}{c}14.71 \\
(1.59,27.82)\end{array}$ & $\begin{array}{c}13.55 \\
(0.00,28.08)\end{array}$ & $\begin{array}{c}15.85 \\
(2.71,29.00)\end{array}$ \\
\hline 36 & $\begin{array}{c}18.43 \\
(0.00,37.08)\end{array}$ & $\begin{array}{c}15.72 \\
(0.42,31.02)\end{array}$ & $\begin{array}{c}13.96 \\
(0.00,29.47)\end{array}$ & $\begin{array}{c}16.39 \\
(0.61,32.17)\end{array}$ \\
\hline 48 & $\begin{array}{c}18.12 \\
(0.00,37.08)\end{array}$ & $\begin{array}{c}16.14 \\
(0.00,33.53)\end{array}$ & $\begin{array}{c}14.99 \\
(0.00,32.13)\end{array}$ & $\begin{array}{c}16.94 \\
(0.00,34.69)\end{array}$ \\
\hline
\end{tabular}

Note: $95 \%$ confidence band in parentheses. 
Graph 1a: End-of-period (EC1) and mid-period cumulative (EC2) excess cash reserves, 1977:8-1991:1

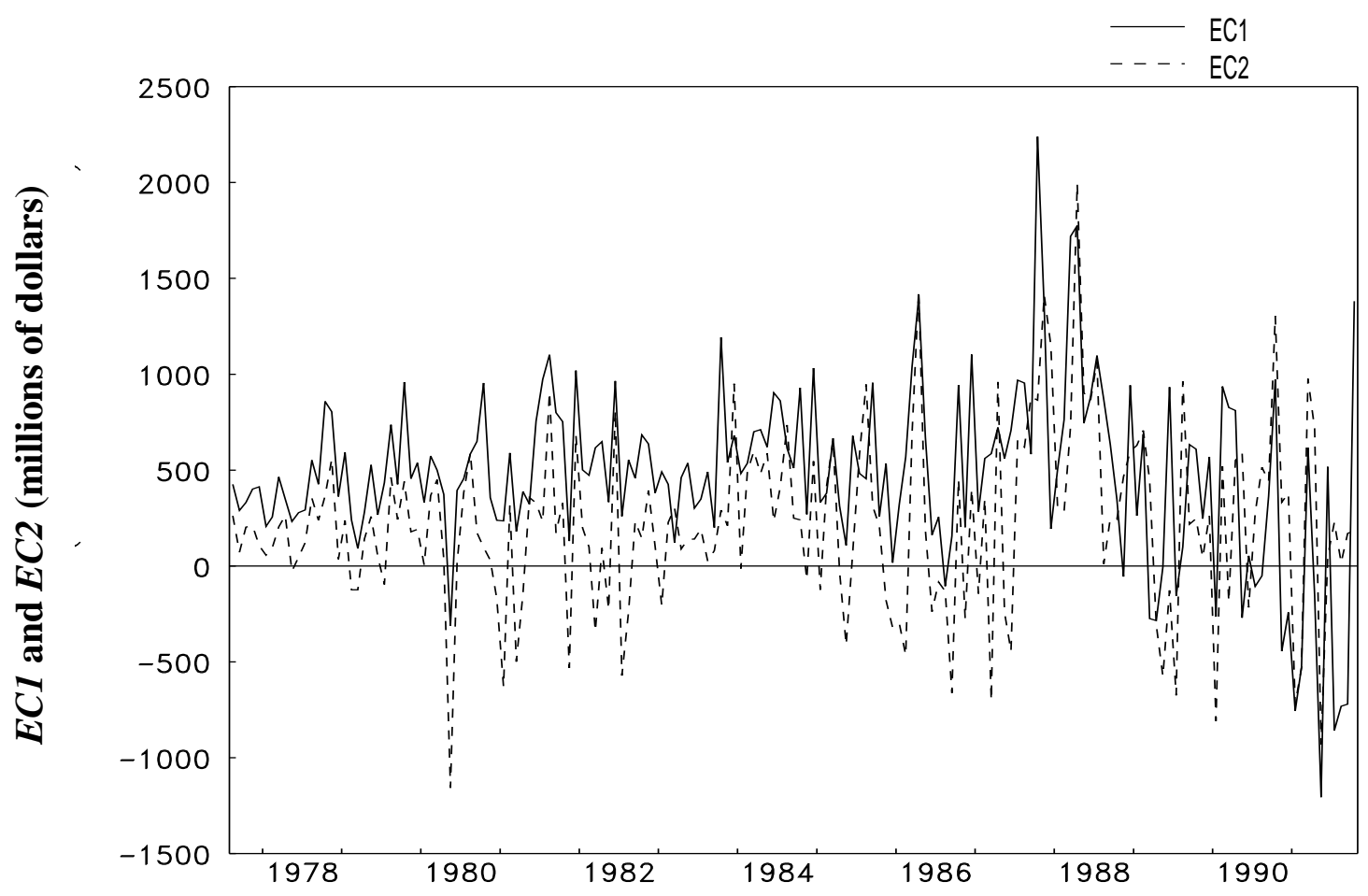

Graph 1b: Cash surprise (CS), 1977:8-1991:10

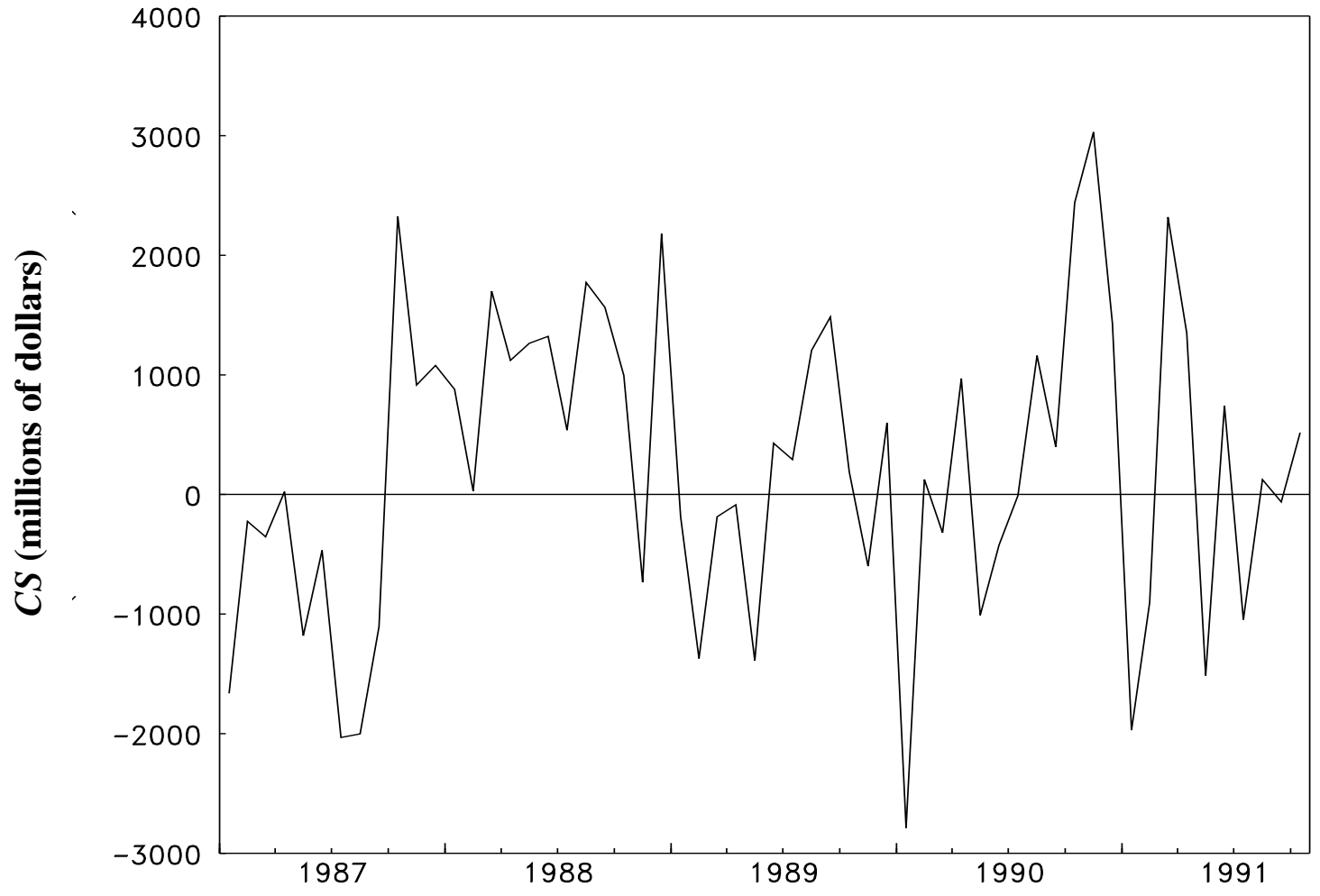




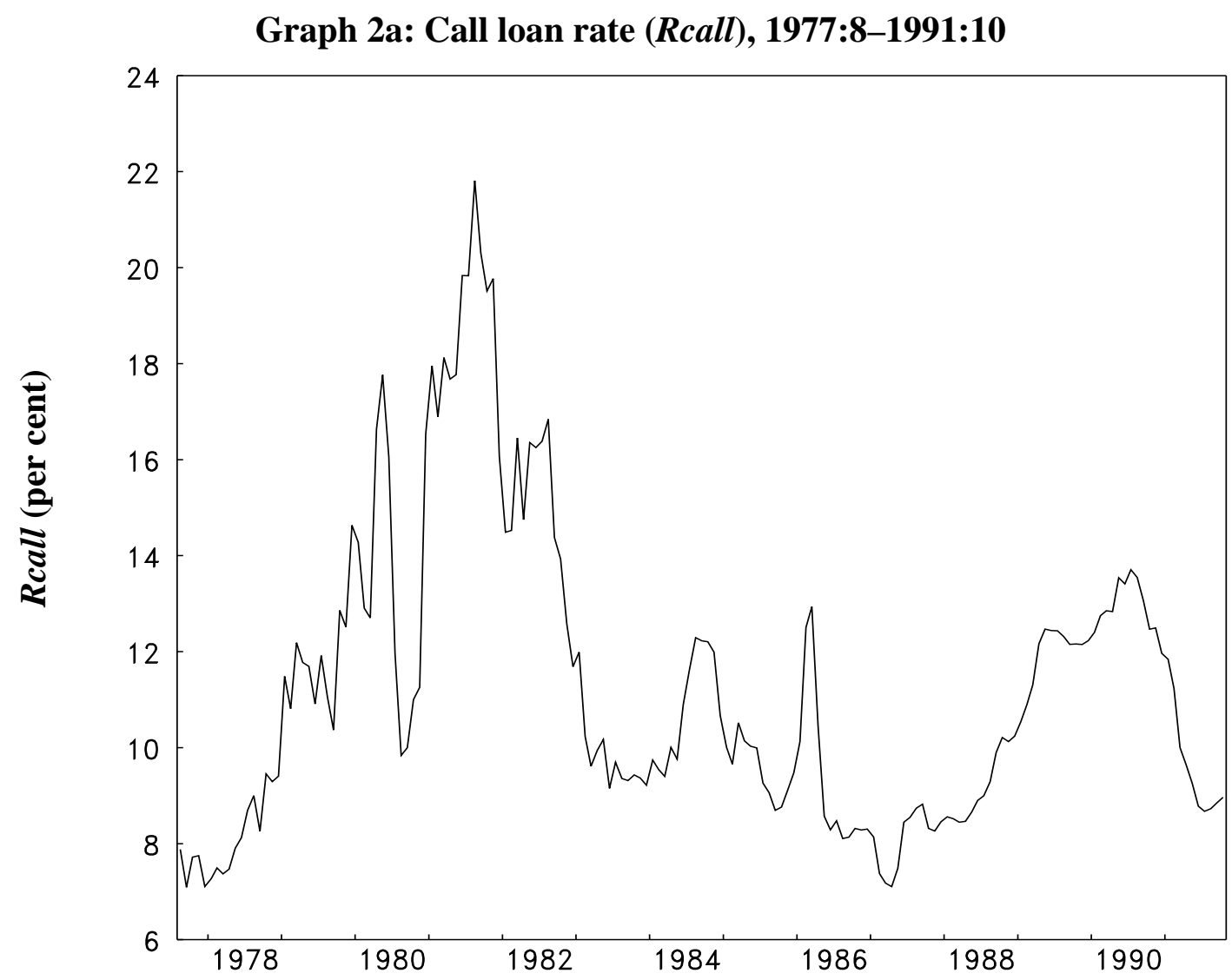

Graph 2b: Call loan rate - 90-day commercial paper rate 1977:8-1991:10

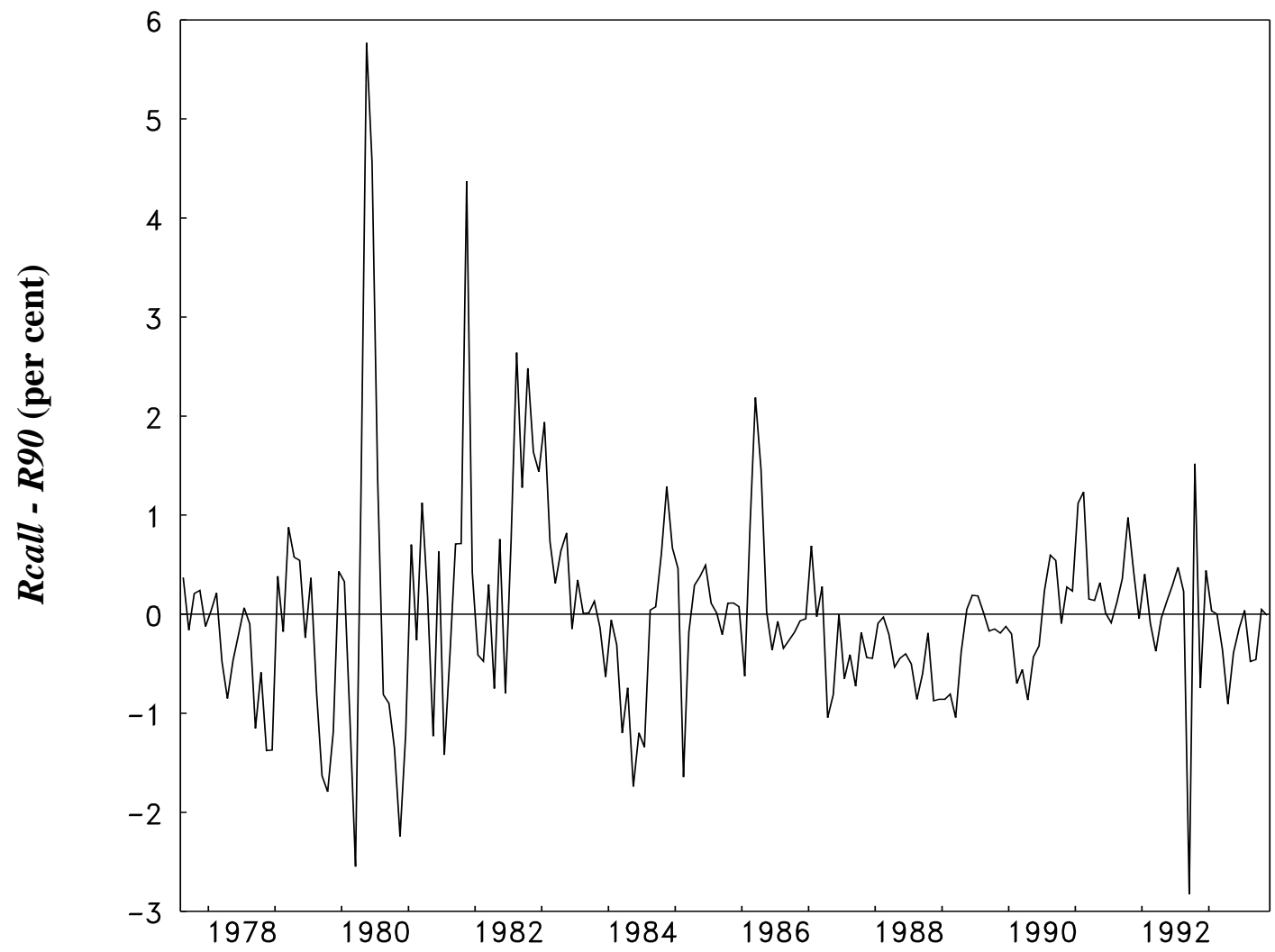



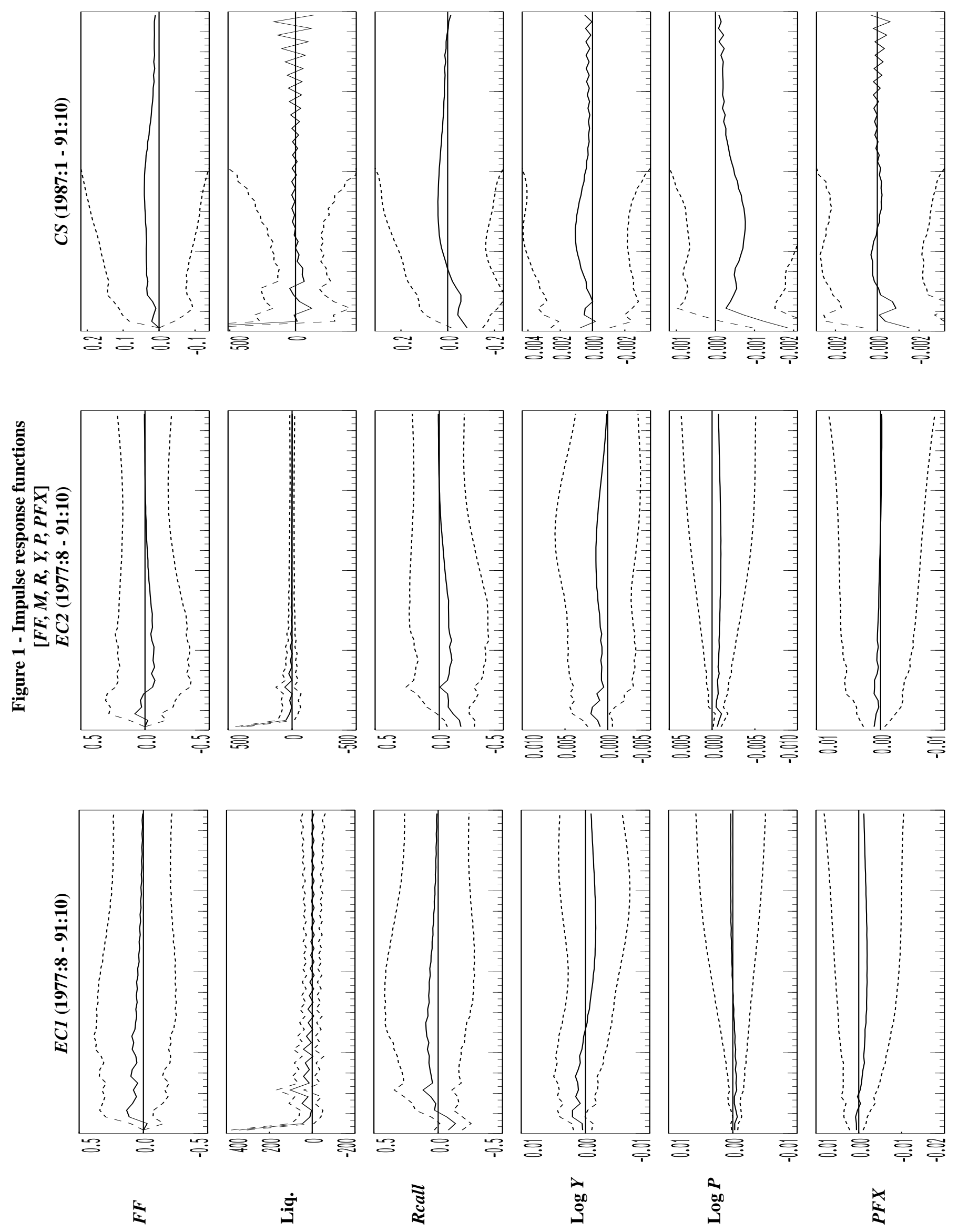

s

ํำ

है

so

촐 

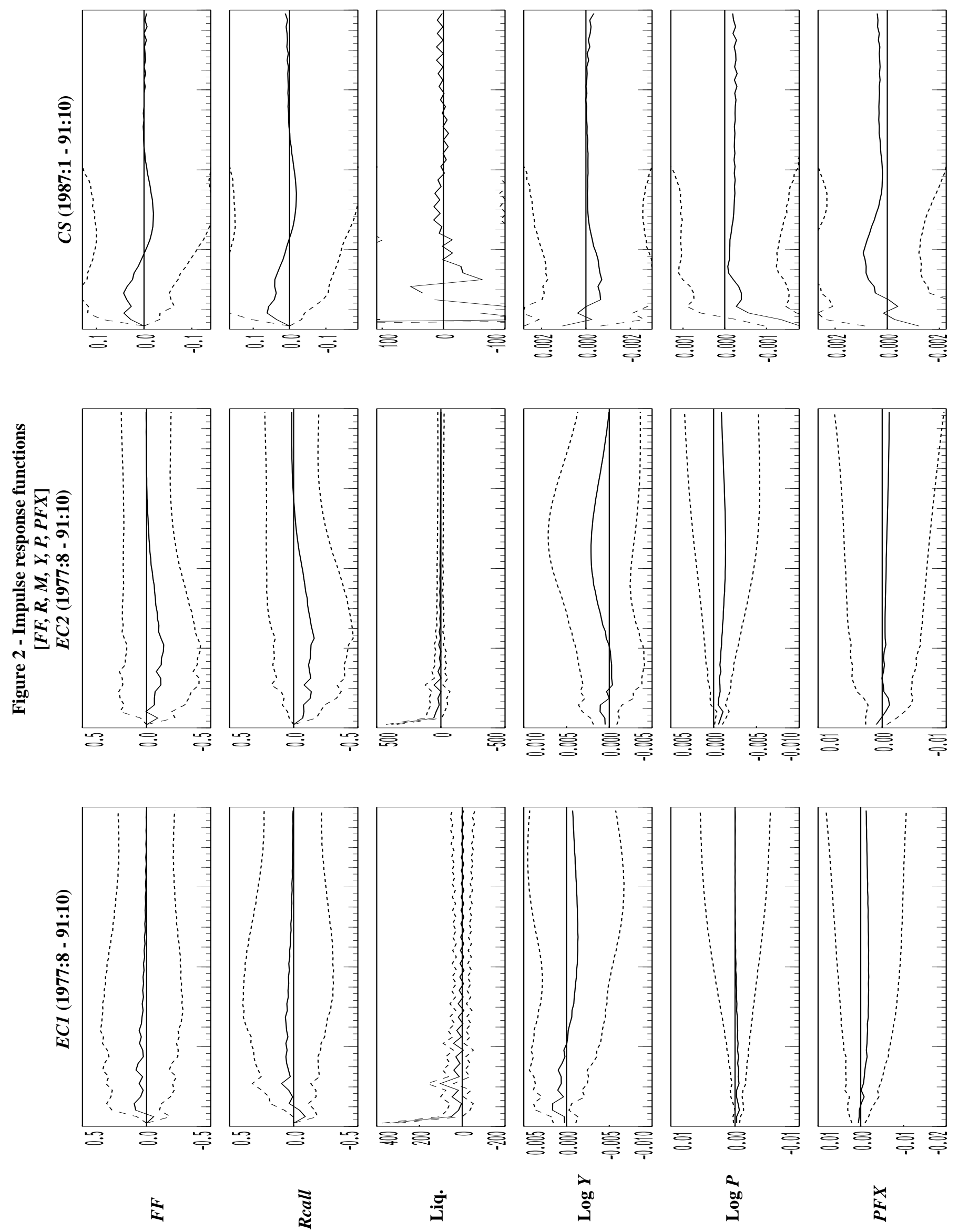

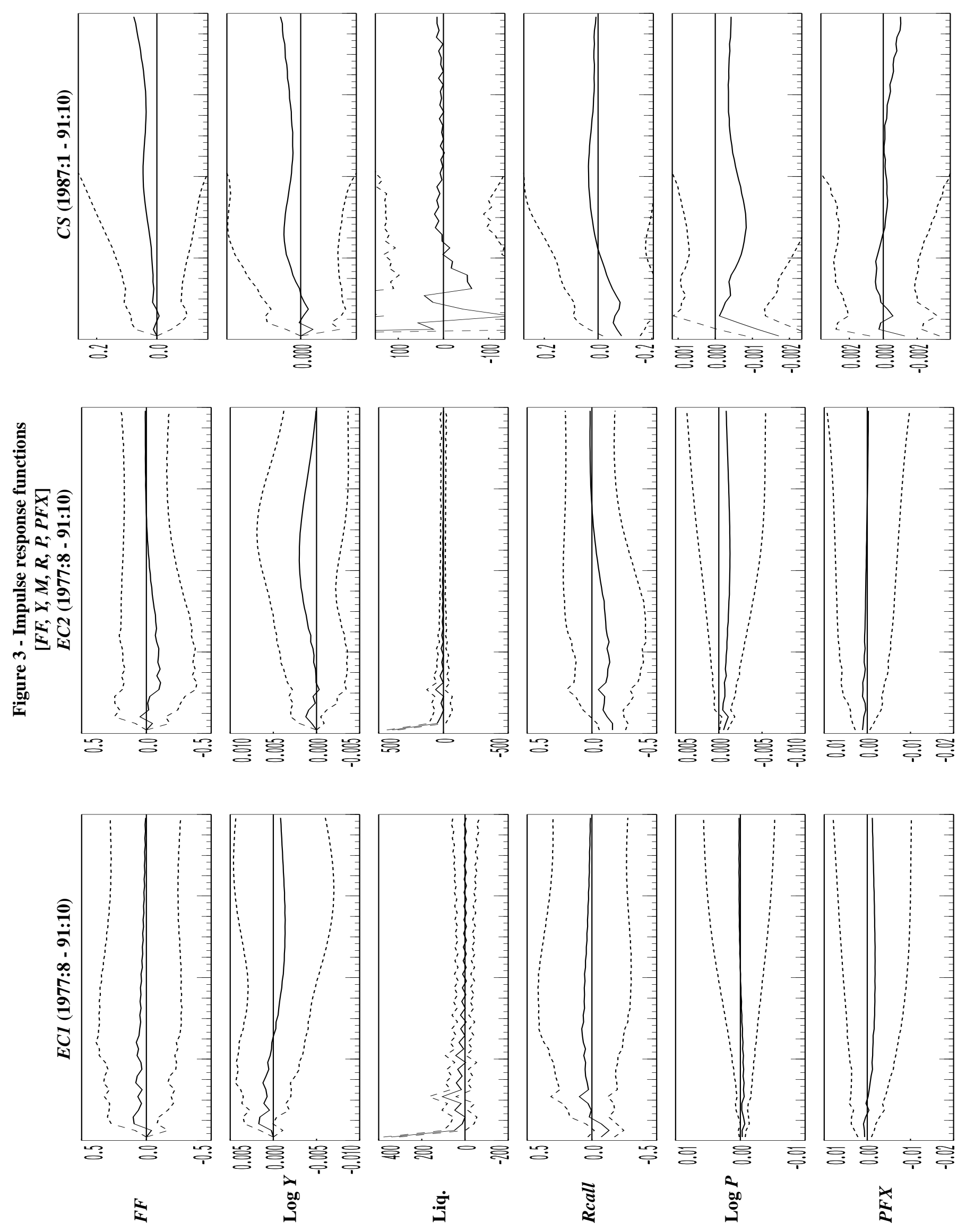

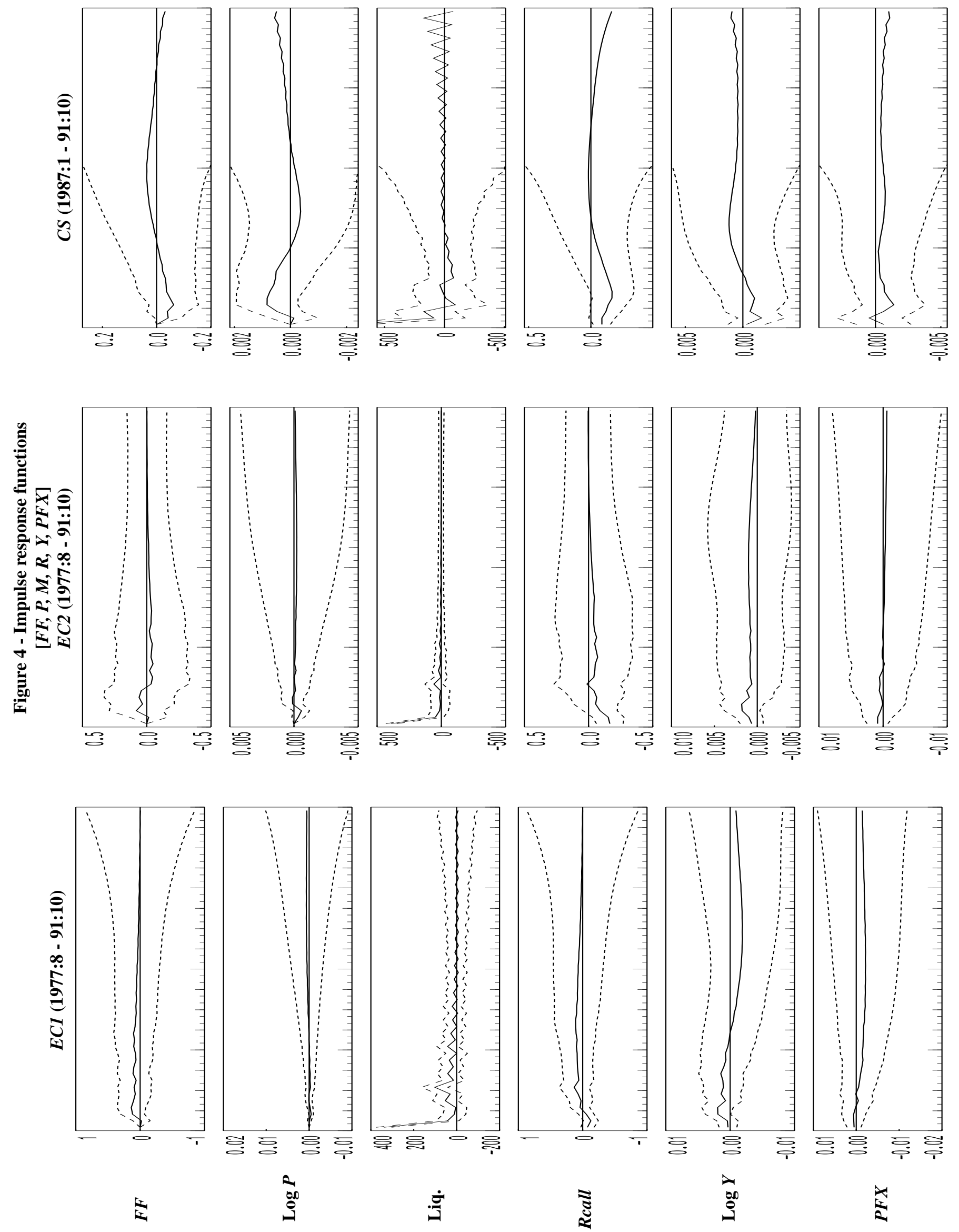

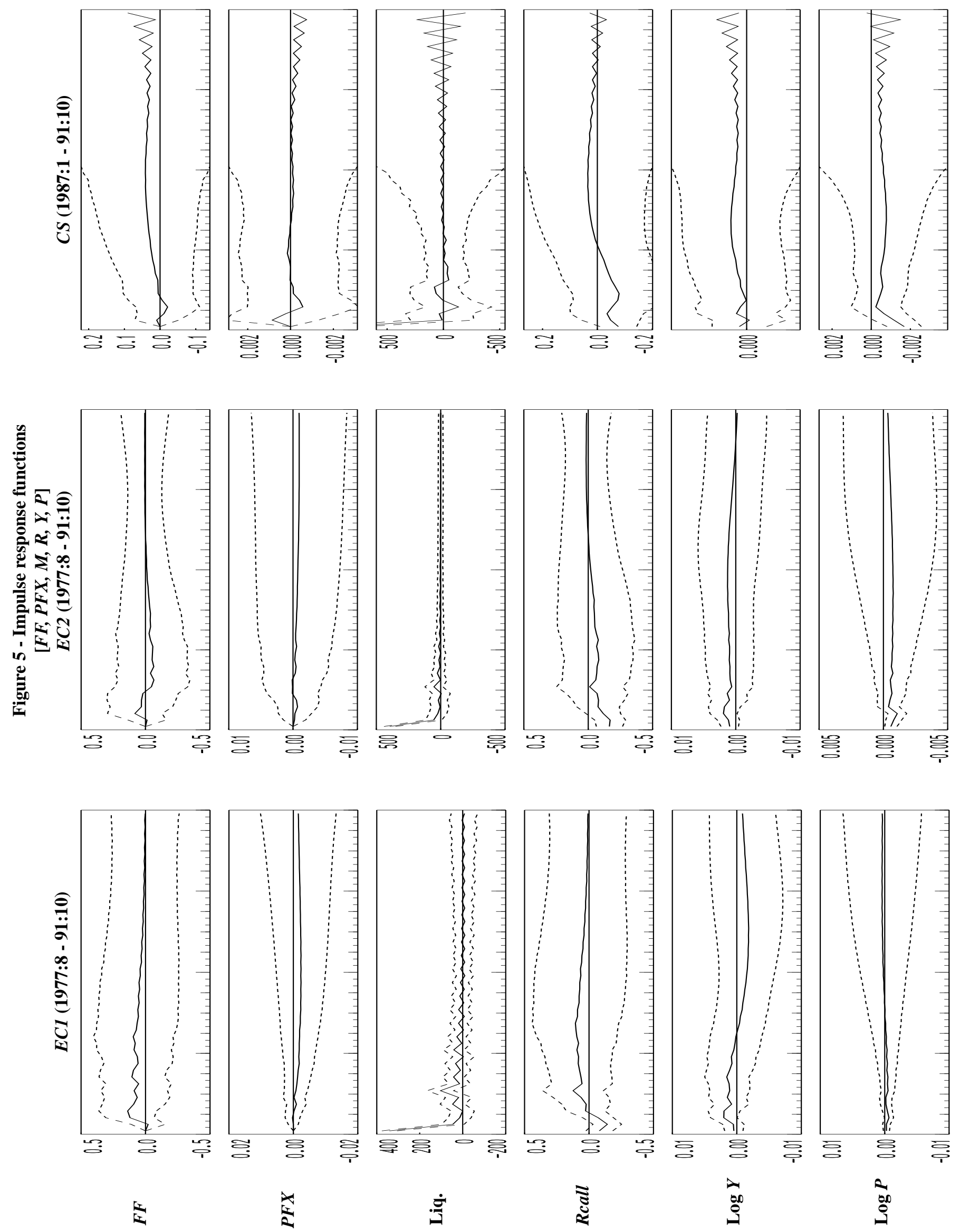

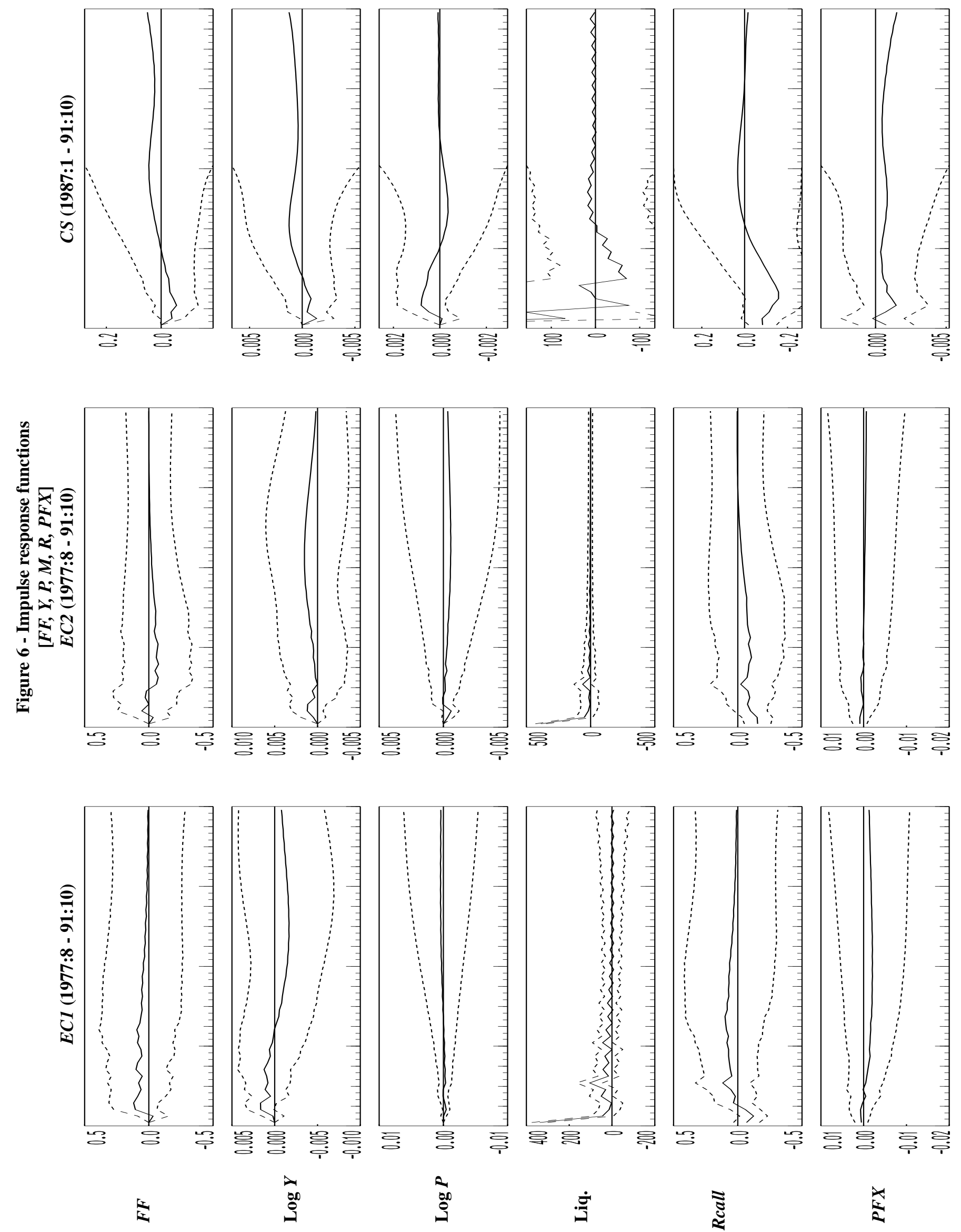

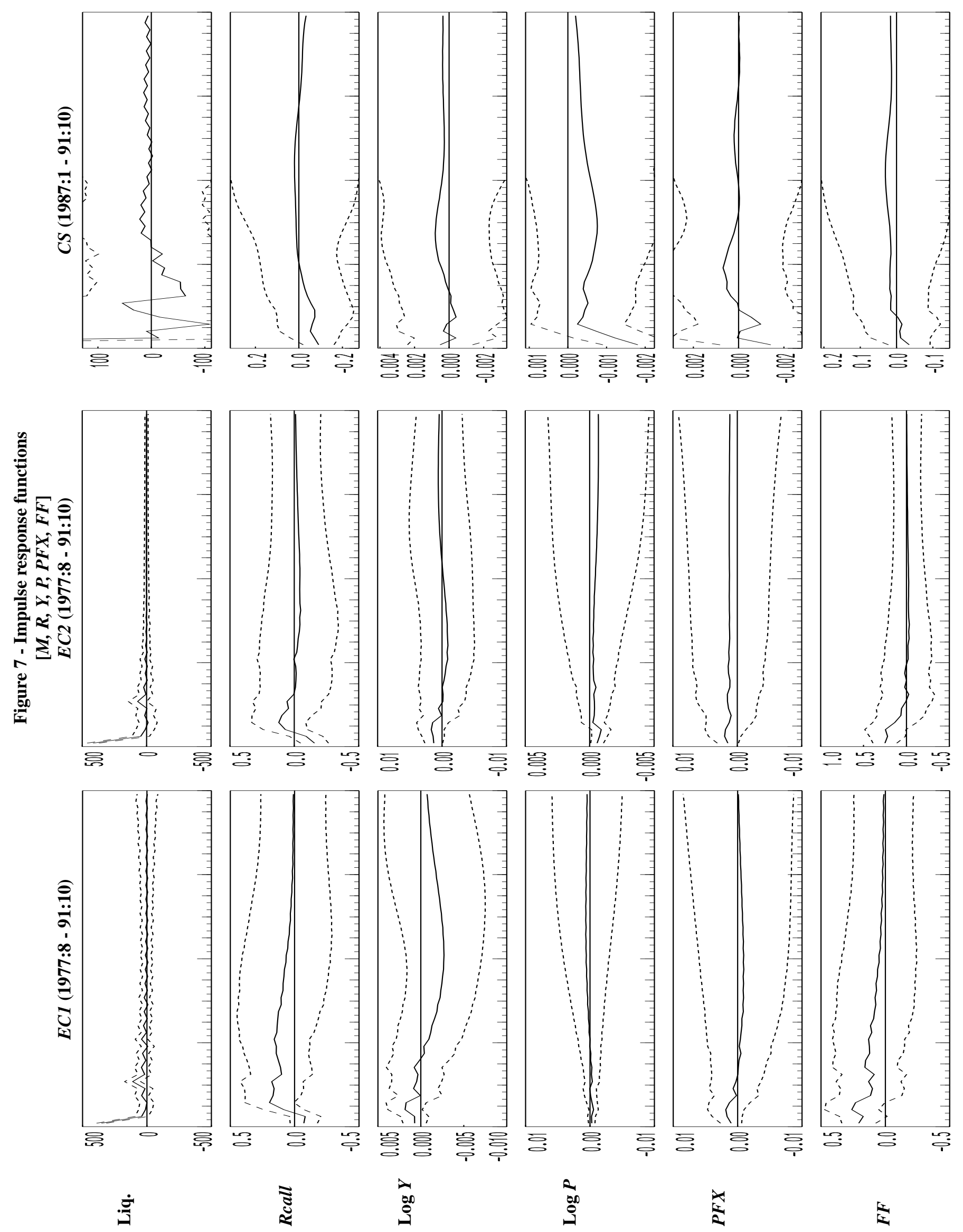

高

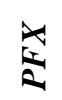

s 

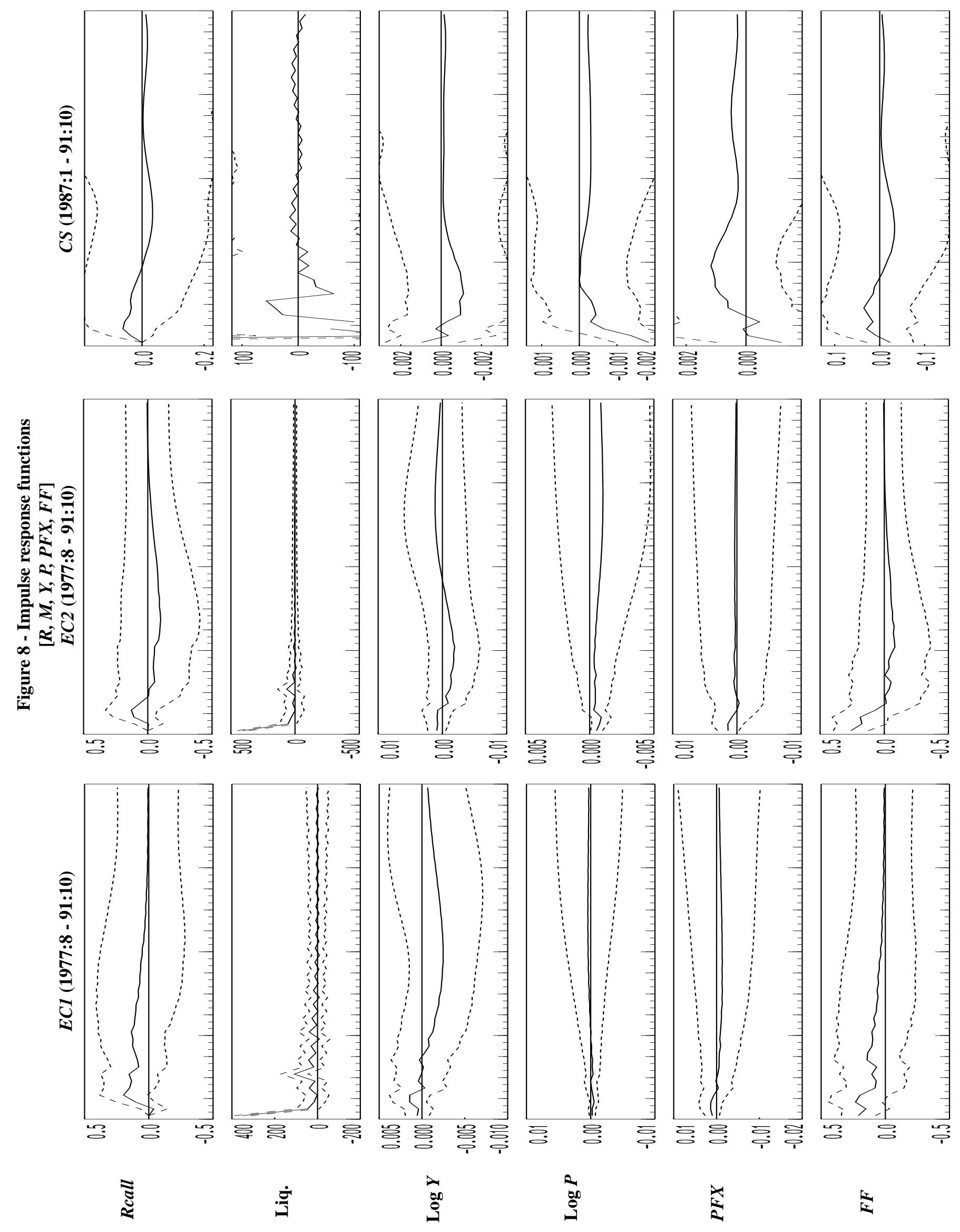

ะ

$\Sigma$ 

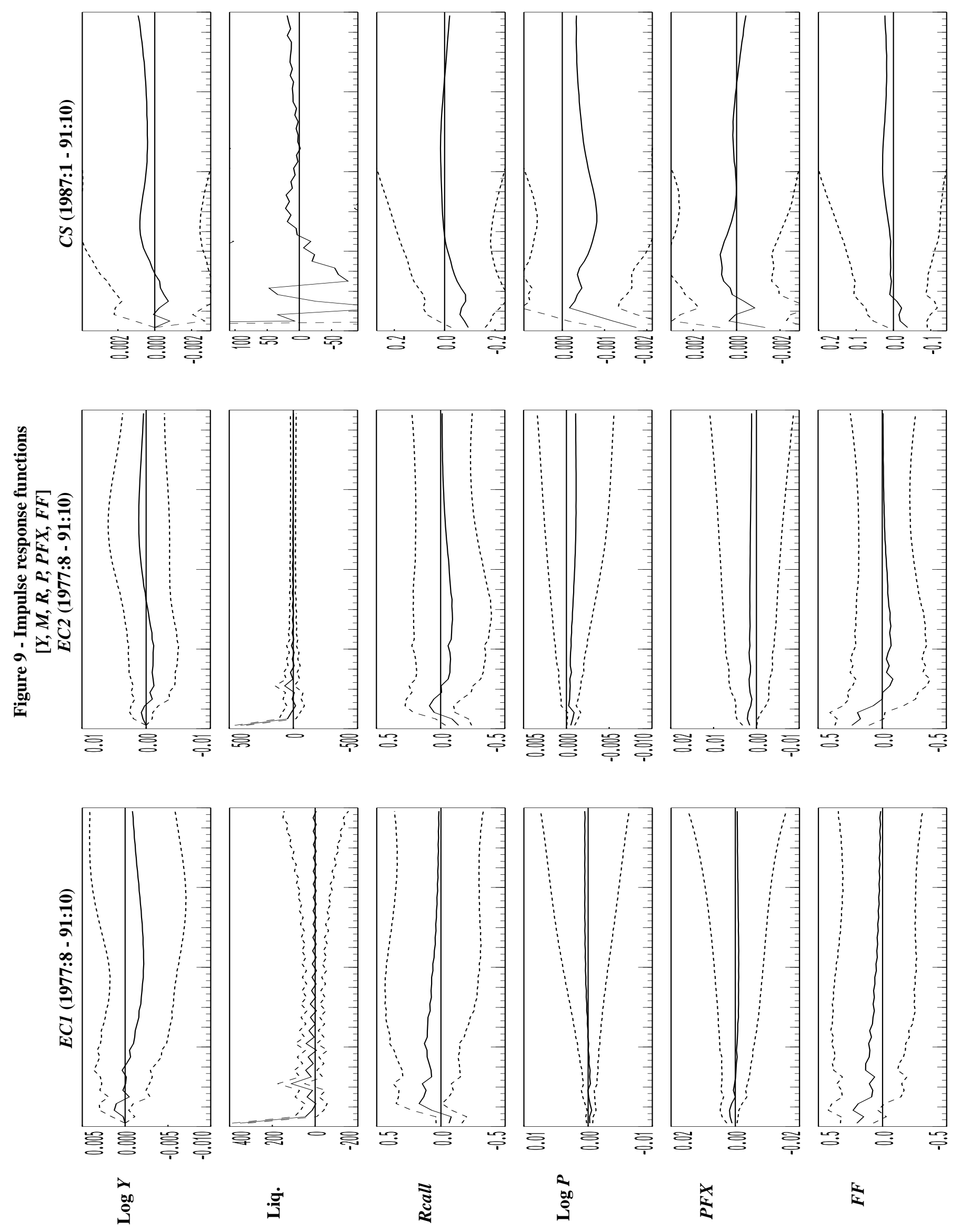

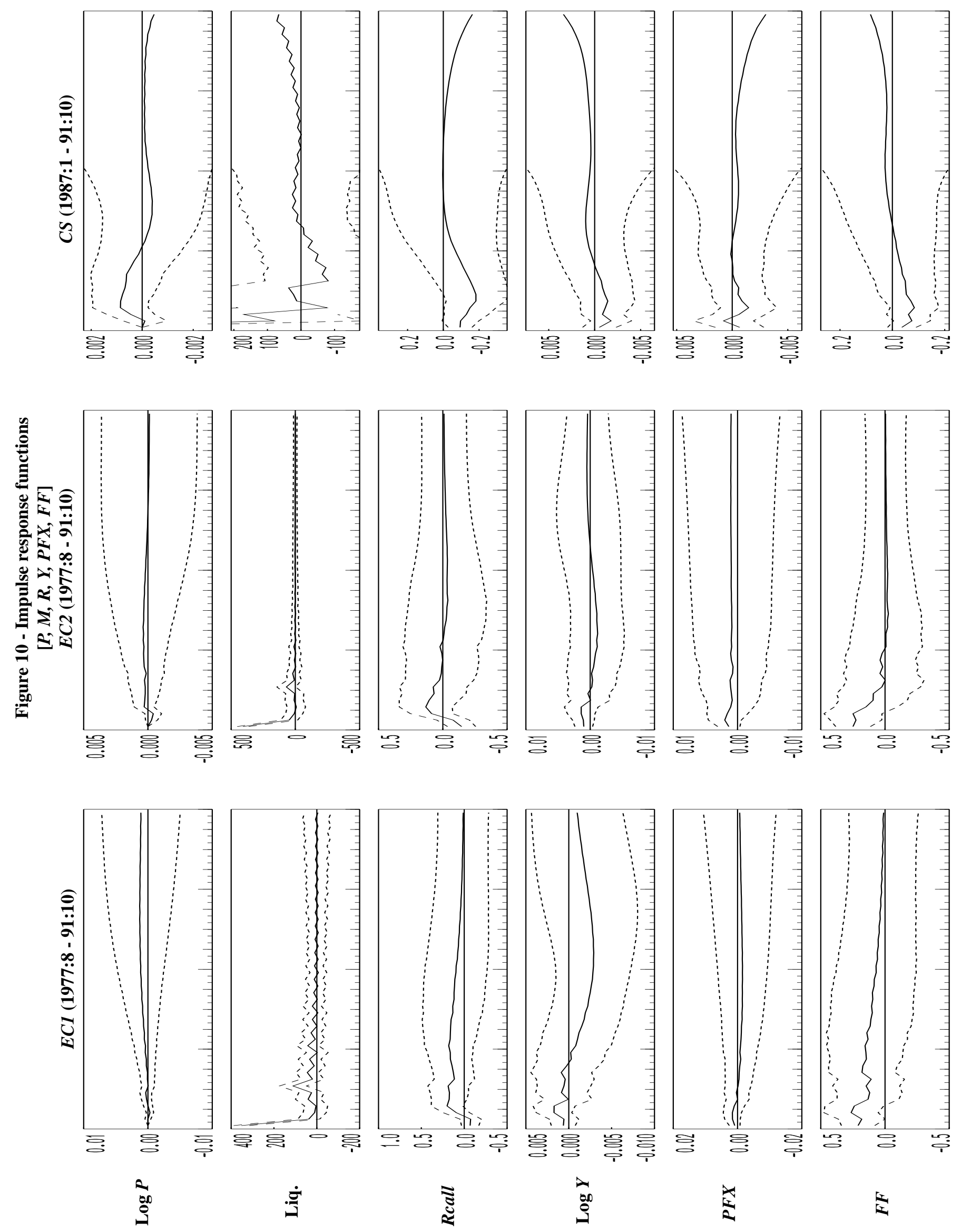

空 

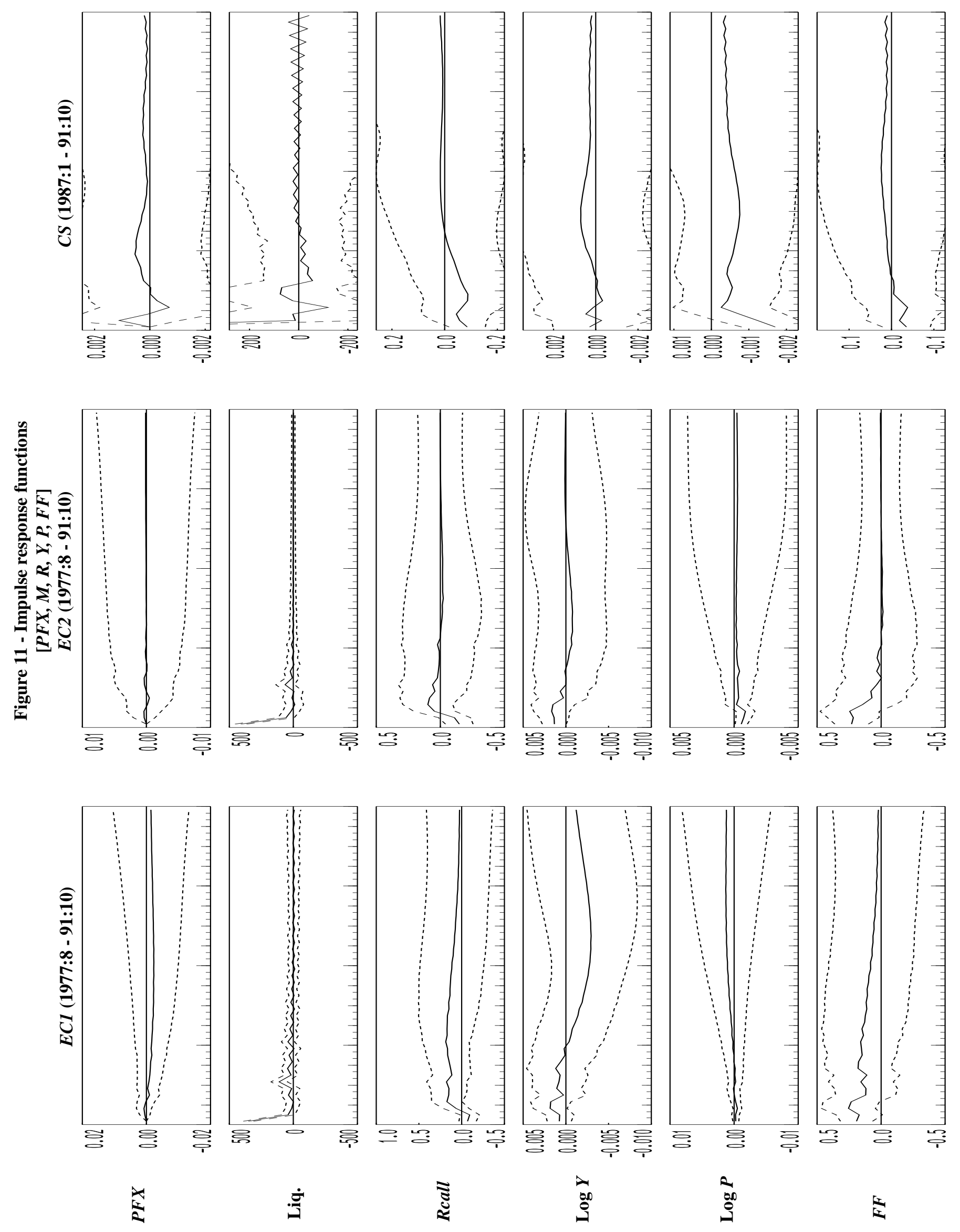

9

$s$ 

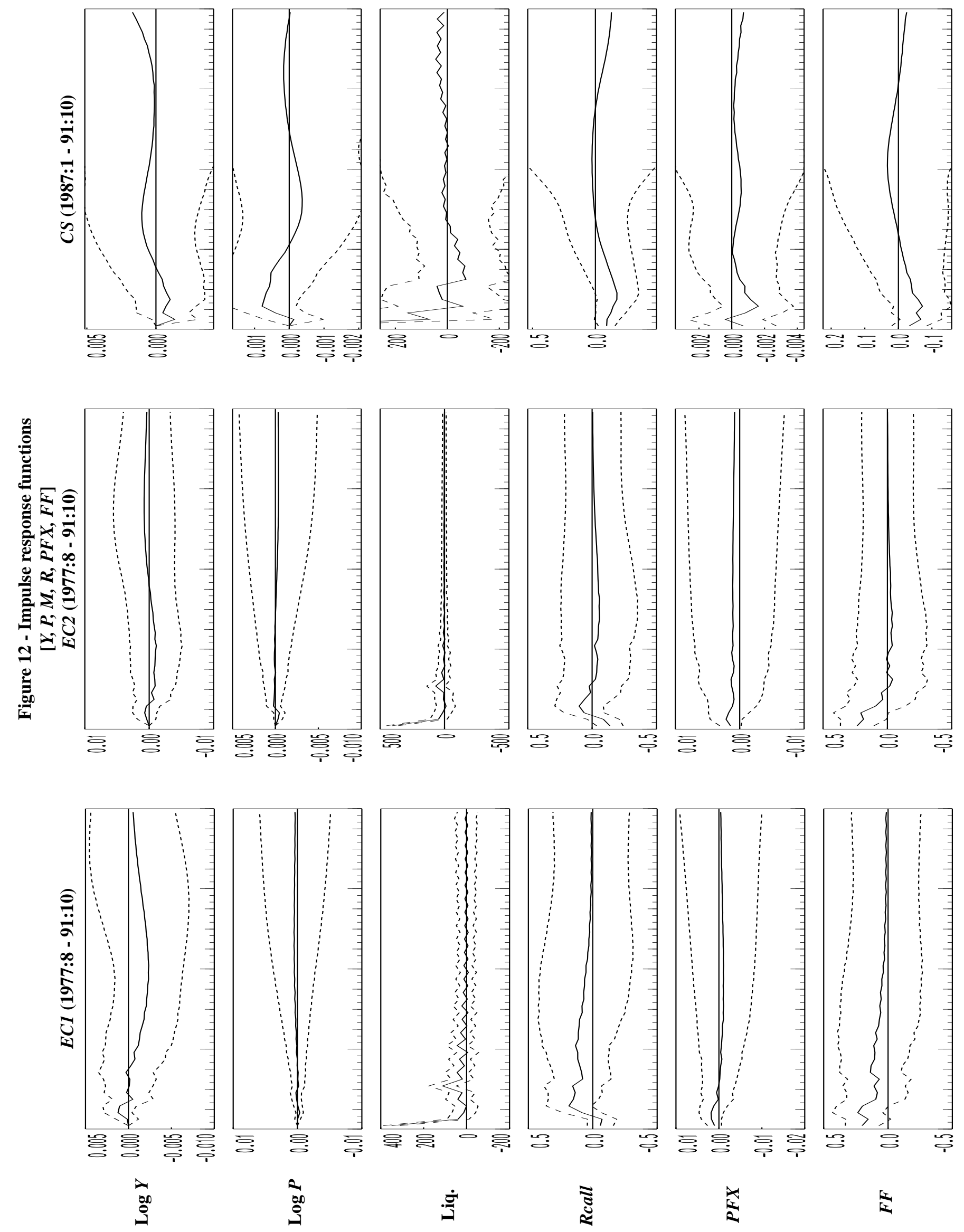

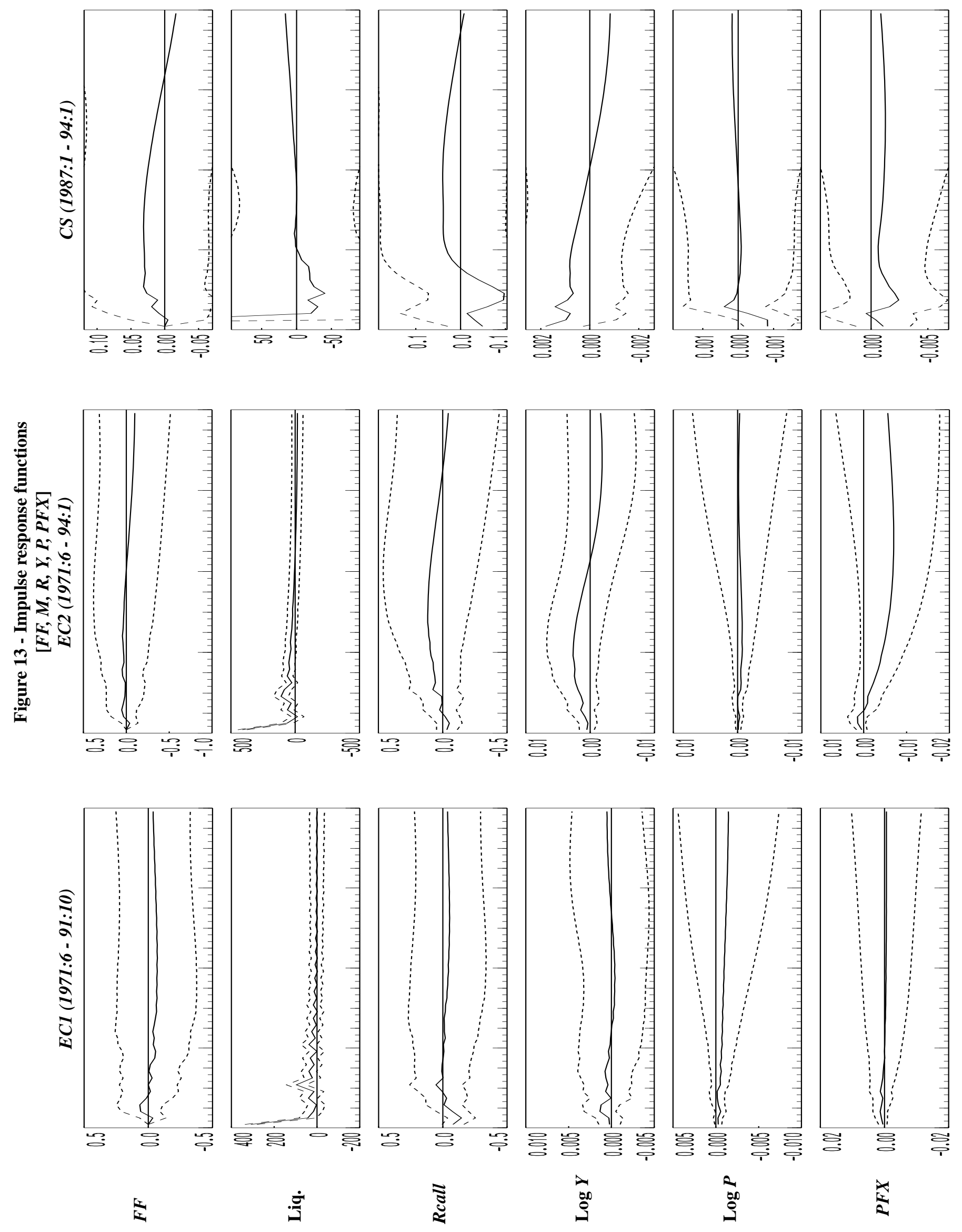

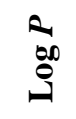

气 

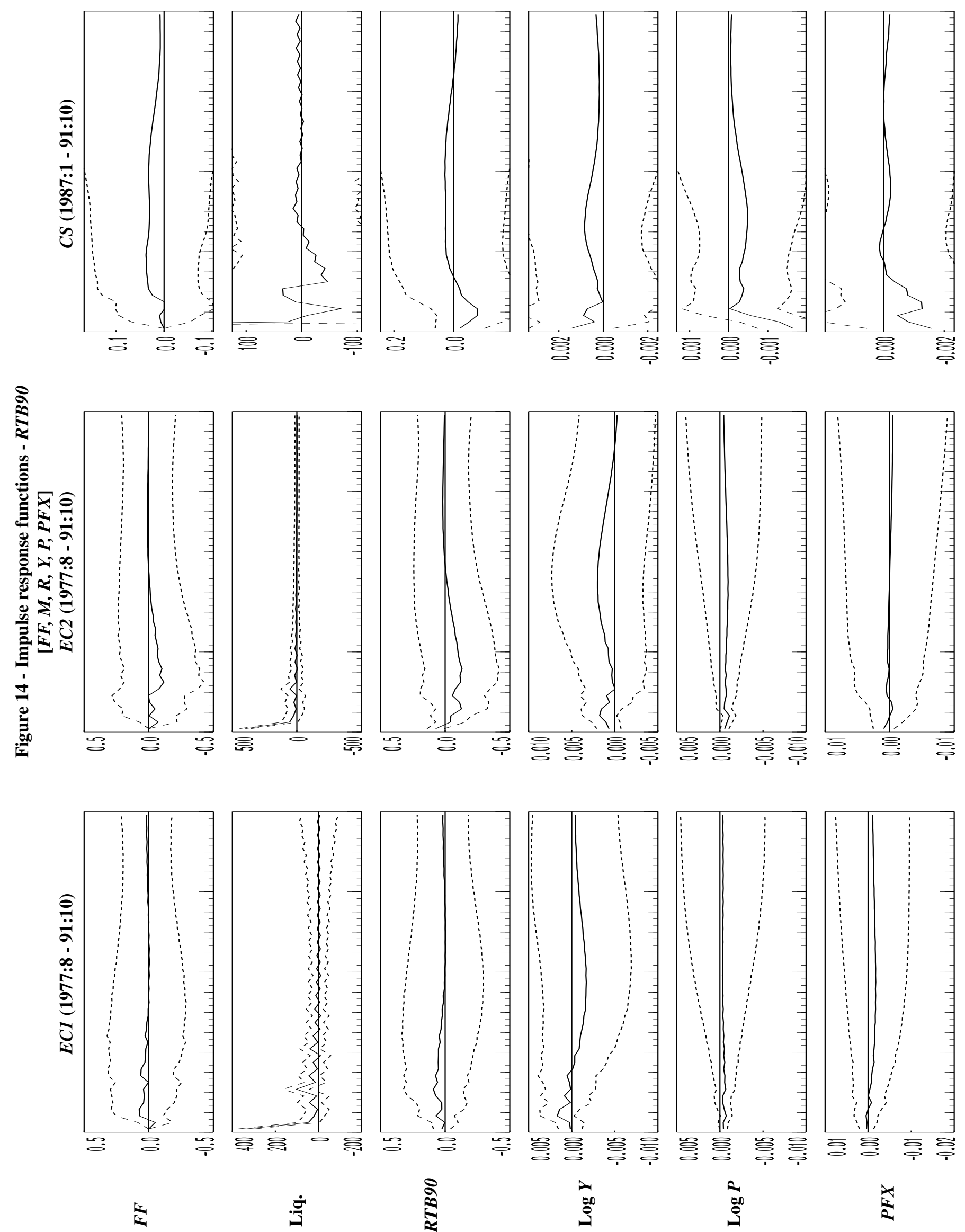

$s$
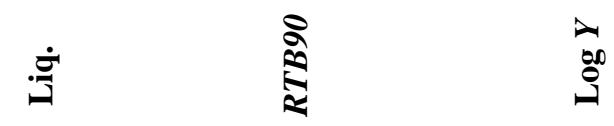

:

총 

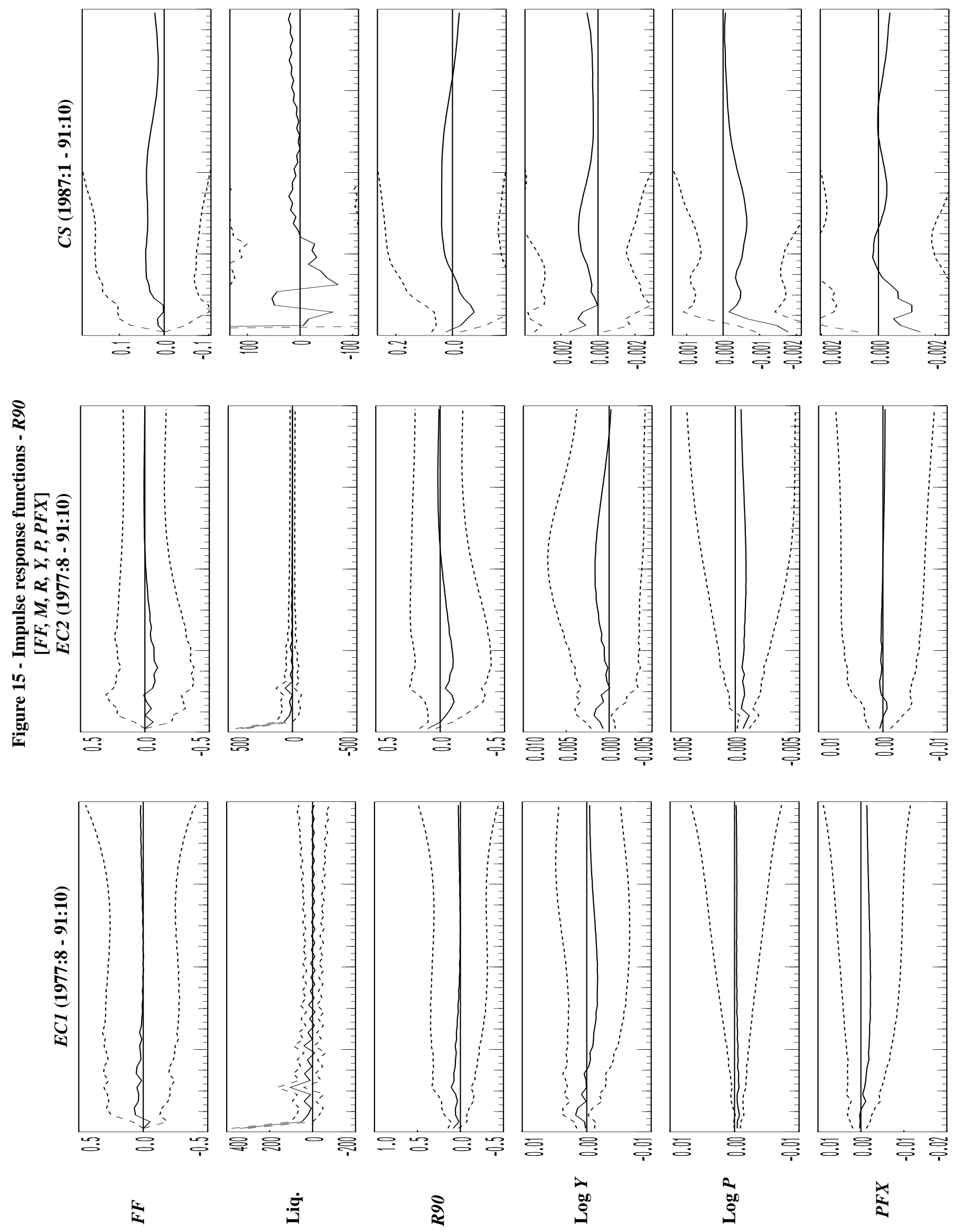

$\frac{1}{2}$ 



\section{Bibliography}

Bernanke, B. S. 1986. “An Alternative Explanation of the Money-Income Correlation.” CarnegieRochester Conference Series on Public Policy (Autumn): 49-100.

Blanchard, O. J. and D. Quah. 1989. “The Dynamic Effects of Aggregate Demand and Supply Disturbances." American Economic Review 79:655-73.

Cagan, P. and A. Gandolfi. 1969. "The Lag in Monetary Policy as Implied by the Time Pattern of Monetary Effects on Interest Rates.” American Economic Review (May): 277-84.

Chamie, N., A. DeSerres, and R. Lalonde. 1994. "Optimal Currency Areas and Shock Asymmetry: A Comparison of Europe and the United States.” Working Paper 94-1. Bank of Canada, Ottawa.

Christiano, L. and M. Eichenbaum. 1992a. "Identification and the Liquidity Effect of a Monetary Policy Shock." In Business Cycles, Growth and Political Economy, edited by L. Hercowitz and L. Leiderman, Cambridge (MA): MIT Press.

. 1992b. "Liquidity Effects, Monetary Policy, and the Business Cycle." Discussion Paper 70. Federal Reserve Bank of Minneapolis, Institute for Empirical Macroeconomics

. 1992c. "Liquidity Effects and the Monetary Transmission Mechanism." American Economic Review (May): 346-53.

Christiano, L., M. Eichenbaum and C. Evans. 1994. "The Effects of Monetary Policy Shocks: Evidence from the Flow of Funds." Working Paper WP-94-2. Federal Reserve Bank of Chicago.

Clinton, K. 1991. "Bank of Canada Cash Management: The Main Technique for Implementing Monetary Policy." Bank of Canada Review (January): 3-25.

Clinton, K. and D. Howard. 1994. From Monetary Policy Instruments to Administered Interest Rates: The Transmission Mechanism in Canada. Technical Report No. 69. Ottawa: Bank of Canada.

Cochrane, J. H. 1989. "The Return of the Liquidity Effect: A Study of the Short-Run Relation Between Money and Growth and Interest Rates." Journal of Business and Economic Statistics 7 (January): 75-83.

Crow, J. W. 1988. “The Work of Canadian Monetary Policy.” Eric J. Hanson Memorial Lecture, Edmonton: University of Alberta. Reprinted in Bank of Canada Review (February): 3-17.

Dingle, J. F., G. R. Sparks and M. A. Walker. 1972. "Monetary Policy and the Adjustment of Chartered Bank Assets." Canadian Journal of Economics 5:494-514.

Doan, T. 1990. Users Manual, RATS Version 3.11. Evanston (IL): VAR Econometrics.

Duguay, P. 1994. "Empirical Evidence on the Strength of the Monetary Transmission Mechanism in Canada: An Aggregate Approach.” Journal of Monetary Economics (February): 39-61. 
Duguay, P. and S. Poloz. 1994. "The Role of Economic Projections in Canadian Monetary Policy Formulation." Canadian Public Policy (June): 189-99.

Eichenbaum, M. and C. Evans. 1993. "Some Empirical Evidence on the Effects of Monetary Policy Shocks on Exchange Rates." Working Paper no. 4271. National Bureau of Economic Research, Cambridge (MA).

Engle, R. F. and C. W. J. Granger. 1987. "Co-integration and Error Correction: Representation, Estimation, and Testing." Econometrica 55:251-76.

Evans, C. L. and F. Santos. 1993. "Monetary Policy Shocks and Productivity Measures in the G-7 Countries.” Working Paper WP-93-12. Federal Reserve Bank of Minneapolis.

Furest, T. 1992. "Liquidity, Loanable Funds and Real Activity." Journal of Monetary Economics 29:3-24.

Gali, J. 1992. “How Well Does the IS-LM Model Fit Postwar U.S. Data?” Quarterly Journal of Economics (May): 709-38.

Gordon, D. B. and E. M. Leeper. 1992. "The Dynamic Impacts of Monetary Policy: An Exercise in Tentative Identification.” Federal Reserve Bank of Atlanta. Mimeo.

Grossman, S. and L. Weiss. 1983. "A Transaction-based Model of the Monetary Transmission Mechanism.” American Economic Review 73:871-80.

Judge, G. C., R. C. Hill, W. E. Griffiths, H. Lutkepohl and T. Lee. 1988. Introduction to the Theory and Practice of Econometrics. 2nd edition. New York: John Wiley \& Sons.

Keating, J. W. 1992. "Structural Approaches to Vector Autoregressions." Federal Reserve Bank of St. Louis Review (Sept./Oct.): 37-57.

King, R. G., C. Plosser, J. Stock and M. Watson. 1991. "Stochastic Trends and Economic Fluctuations." American Economic Review (Sept.): 819-40.

Leeper, E. M. and D. Gordon. 1992. "In Search of the Liquidity Effect." Journal of Monetary Economics (June): 341-69.

Lucas, R. E. Jr. 1990. “Liquidity and Interest Rates.” Journal of Economic Theory 50 (April): 237-64.

Melvin, M. 1983. "The Vanishing Liquidity Effect of Money on Interest: Analysis and Implications for Policy." Economic Inquiry 21 (April): 188-202.

Rotemberg, J. 1984. “A Monetary Equilibrium Model with Transactions Costs.” Journal of Political Economy 92:40-58.

Shapiro, M. D. and M. W. Watson. 1988. "Sources of Business Cycle Fluctuations." In NBER Macroeconomics Annual, edited by S. Fischer. Cambridge (MA): MIT Press.

Sims, C. 1986. “Are Forecasting Models Usable for Policy Analysis?” Federal Reserve Bank of Minneapolis Quarterly Review (Winter): 2-16. 
Sims, C. 1992. "Interpreting the Macroeconomic Time Series Facts: The Effects of Monetary Policy." European Economic Review 36 (June): 975-1000.

Sims, C., J. Stock and M. Watson. 1990. "Inference in Linear Time Series Models with Some Unit Roots." Econometrica 58:113-44.

Strongin, S. 1992. "The Identification of Monetary Policy Disturbances: Explaining the Liquidity Puzzle.” Working Paper (wp-92-27). Federal Reserve Bank of Chicago.

Watson, M. W. 1993. "Vector Autoregressions and Cointegration.” Working Paper wp-93-14, Federal Reserve Bank of Chicago.

White, W. R. and S. S. Poloz. 1980. "Monetary Policy and Chartered Bank Demand Functions for Excess Cash Reserves.” Canadian Journal of Economics (May): 189-205. 



\section{Bank of Canada Working Papers}

1994

94-1 Optimum Currency Areas and Shock Asymmetry:

A Comparison of Europe and the United States

N. Chamie, A. DeSerres and R. Lalonde

94-2 A Further Analysis of Exchange Rate Targeting in Canada

R. A. Amano and T. S. Wirjanto

94-3 The Term Structure and Real Activity in Canada

B. Cozier and G. Tkacz

94-4 An Up-to-Date and Improved BVAR Model

of the Canadian Economy

D. Racette, J. Raynauld

and C. Sigouin

94-5 Exchange Rate Volatility and Trade: A Survey

A. Côté

94-6 The Dynamic Behaviour of Canadian Imports and the Linear-

R. A. Amano

Quadratic Model: Evidence Based on the Euler Equation

and T. S. Wirjanto

94-7 L'endettement du secteur privé au Canada : un examen macroéconomique

J.-F. Fillion

94-8 An Empirical Investigation into Government Spending and Private Sector Behaviour

R. A. Amano and T. S. Wirjanto

94-9 Symétrie des chocs touchant les régions canadiennes et choix d'un régime de change

A. DeSerres and R. Lalonde

94-10 Les provinces canadiennes et la convergence : une évaluation empirique

M. Lefebvre

94-11 The Causes of Unemployment in Canada: A Review of the Evidence

S. S. Poloz

94-12 Searching for the Liquidity Effect in Canada

B. Fung and R. Gupta

1993

(Earlier 1993 papers, not listed here, are also available.)

93-12 Zones monétaires optimales : cas du Mexique et des États-Unis

R. Lalonde and P. St-Amant

93-13 Is Productivity Exogenous over the Cycle?: Some Canadian

Evidence on the Solow Residual

B. Cozier and

R. Gupta

93-14 Certainty of Settlement and Loss Allocation with a Minimum of Collateral

W. Engert

93-15 Oil Prices and the Rise and Fall of the U.S. Real Exchange Rate

R. A. Amano and S. van Norden

Single copies of Bank of Canada papers may be obtained from

Publications Distribution

Bank of Canada

234 Wellington Street

Ottawa, Ontario K1A 0G9 